\title{
Twin Imperial Disasters. The invasions of Khiva and Afghanistan in the Russian and British official mind, 1839-1842*
}

\author{
ALEXANDER MORRISON \\ Department of History, University of Liverpool, Liverpool, UK \\ Email:a.s.morrison@liverpool.ac.uk
}

This paper examines two linked cases of abortive Imperial expansion. The British invasion of Afghanistan and the Russian winter expedition to Khiva both took place in 1839, and both ended in disaster. These events were linked, not merely by coincidence, but by mutual reactions to intelligence received in Orenburg, St Petersburg, Calcutta, London and Tebran. British and Russian officials shared similar fears about each other's ambitions in Central Asia, similar patterns of prejudice, arrogance and ignorance, and a similar sense of entitlement as the selfconscious agents of two 'Great Powers'. By examining the decision-making process which preceded these twin cases of expansion, and the British and Russian attitude to Central Asian rulers and informants, the paper provides not only a deeper understanding of what provoked these particular disasters, but also of the wider process of European imperial expansion in the early nineteenth century.

\section{Introduction}

'Ici il faut agir a l'anglaise, et cela d'autant plus que c'est contre les Anglais qu'on agit.'

In 1839 Britain and Russia both overreached themselves in an abortive advance into Central Asia. Lord Auckland's occupation of Afghanistan and General Perovsky's attempt to invade Khiva are central episodes in the grand narrative of imperial competition and conquest generally known as the 'Great Game' - a narrative in which Central Asians themselves are usually presented either as bystanders or as a sort of deadly deus ex machina, whose only role in the drama was to mete out bloody punishment to the Europeans whose deluded antics always take centre stage. The British were marginal actors in Central Asia, and even the Russians—-who ended up conquering most of

\footnotetext{
* The research for this paper was funded by the Warden and Fellows of All Souls College, Oxford, and by the British Academy. I would like to thank the Slavic Research Centre of Hokkaido University, where I wrote the initial version of this paper while on a Visiting Fellowship, and in particular Professor Uyama Tomohiko for his comments. I would also like to thank William Dalrymple, Michael Hopkins, Michael Hughes, Richard Huzzey, Clare Jackson, Beatrice Penati, Berny Sèbe, Shioya Akifumi, Rory Stewart, Kim Wagner, Tom Welsford, and the anonymous reviewers for Modern Asian Studies for their suggestions, which have enormously improved it.

1 'Here we must act as the English do, all the more so because it is against the English that we are acting': Perovsky to Bulgakov, 4 February 1840, 'Pis'ma grafa V.A. Perovskago k A. Ya Bulgakovu', Russkii Arkhiv [RA], (1878) No. 7 Letter 9 p. 309
} 
2 A. Morrison 'Twin Imperial Disasters. The invasions of Khiva and Afghanistan in the Russian and British official mind, 1839 - 1842' Modern Asian Studies Vol.48 No.1 (2014) pp.253 - 300

it - should not always be at the heart of any history of the conquest. For all the glamour surrounding the competition between two Great Powers in an exotic and little-known land, it was those who actually lived there who would face the greatest long-term consequences of this imperial competition, which, in many respects, endure to this day.

That said, this paper does not focus on what it was like to be on the receiving end of an invading army, nor on the many profound changes that these military incursions would eventually make in the lives of Central Asians. Neither does it aim to provide a description of these 'disasters' and their causes: instead I wish to focus on the process of decision-making that preceded these twin episodes, to examine them comparatively, and to consider the extent to which they were linked, not simply by coincidence, but through mutual reaction to political intelligence in St Petersburg, Orenburg, London, and Calcutta. Although Russia and Britain ostensibly had rather different systems of government in this period, in both cases the crucial decisions were taken by small coteries of officials acting without any real legislative oversight—in the Russian case because there was no legislature, in the British case because before the second half of the twentieth century, parliament, and indeed the cabinet, had little direct control over British foreign policy, and still less over that of the government of India. ${ }^{2}$ My contention is that these British and Russian officials, whether in the metropole or 'on the spot', shared a common militarybureaucratic institutional culture, common patterns of prejudice and ignorance, and a sense of sheer entitlement that came from their self-identification as agents of the European 'Great Powers'. The latter was an idea that had come into increasingly widespread use after the Congress of Vienna, initially as a means of categorizing European states. ${ }^{3}$ It is sometimes assumed that Britain's global pre-eminence remained largely uncontested for almost 50 years after the defeat of Napoleon, before a more competitive international landscape helped to provoke a final, frenzied phase of European expansion after 1870. In fact, the political settlement of 1815 had left two European powers with the ability to act on a global, and not merely European, stage, namely Britain and Russia, whose rivalry was already clear to the future war minister and supporter of the Khiva expedition, A. I. Chernyshev, at the Congress of Vienna in $1814 .{ }^{4}$ Certain patterns of behaviour were expected of these mutually identified 'Great Powers' in order to uphold that

${ }^{2}$ Joseph Frankel, 'Towards a Decision-Making Model in Foreign Policy', Political Studies Vol. 7 No. 1 (1959) p. 2; David Reynolds, Britannia Overruled. British Policy and World Power in the Twentieth Century (London: Longman, 1991) p. 38; Zara S. Steiner, The Foreign Office and Foreign Policy, 1898-1914 (Cambridge: Cambridge UP, 1969) p. 2; John Darwin, Imperialism and the Victorians. The Dynamics of Territorial Expansion', English Historical Review Vol. CXII No. 447 (1997) pp. 624-27.

${ }^{3}$ The popularization of the term 'Die Grossen Mächte' is usually attributed to Leopold von Ranke: see Paul Kennedy, The Rise and Fall of the Great Powers (London: Unwin Hyman, 1988) pp. xxiv-xxv; Leopold Ranke, 'Die Grossen Mächte', Historisch-Politische Zeitschrift Vol. II (1833), pp. 1-51, although it seems to have been used by statesmen and diplomats well before it was adopted by historians. By the 1830s, together with its concomitant 'lesser powers', it was already current in Anglophone historiography: see Sir Archibald Alison, History of Europe from the Commencement of the French Revolution in M.DCC.LXXXIX to the Restoration of the Bourbons in M.DCCC.XV (Edinburgh: Wm Blackwood, 1835-1842) Vol. I, p. 157; Vol. II, pp. 254-56, 288-95, 599-600; Vol. V, pp. 305-07; Vol. X, pp. 57, 196, 201, 382, 521, 769, 979.

4 'Si depuis la chute de Napoléon l'Europe a une oppression à craindre, c'est uniquement de la part de l'Angleterre' ('If since the fall of Napoleon, Europe has an oppression to fear, it is solely on the part of England'): 'Dokladnaya Zapiska A.I. Chernysheva Imperatoru Aleksandru I' n.d. (April 1814), Sbornik Imperatorskago Russkago Istoricheskago Obshchestva (St Petersburg: Imperial Russian Historical Society, 1906) Vol. 121, pp. 280-81 
A. Morrison 'Twin Imperial Disasters. The invasions of Khiva and Afghanistan in the Russian and British official mind, 1839 - 1842' Modern Asian Studies Vol.48 No.1 (2014) pp.253 - 300

elusive quality, imperial prestige. ${ }^{5}$ Beyond Europe, this meant that what were previously more symbiotic, if not equal, relationships with 'Asiatic' or 'native' states as well as those with local elites in existing colonies were increasingly couched in terms of overwhelming European cultural and racial superiority. As many scholars have argued, this growing arrogance and intolerance played a crucial role in stimulating and justifying imperial expansion and dominion, but what is less often acknowledged is that these attitudes could also provoke intelligence failures and 'information panics' that simultaneously undermined imperial control. ${ }^{6}$ It was largely as a result of ignoring local advice and disregarding or misinterpreting information from 'native' sources, as well as a refusal to engage in serious diplomatic negotiations with Central Asian states, that the Khiva and Afghanistan expeditions were launched, and then ended in disaster.

It is in the nature of disasters that they attract much historical attention, and these two are no exception. In the case of the Khiva expedition the immediate reason for its failure-the severe winter of 1839-40 - has always been clear and uncontroversial and detailed descriptions of the march are to be found in many contemporary and later sources. ${ }^{7}$ Its motives and longer-term consequences are less well understood: there is no recent English-language historiography on the subject, while the standard accounts in Russian still date from the Tsarist period and are almost impossible to disentangle from the politics of Russian imperialism in the region. The tone was set by the earliest comprehensive account, drawn up by General M.I. Ivanin on Perovsky's instructions, which is largely a description of Khivan perfidy and a celebration of Russian heroism and endurance, together with a certain amount of score-settling with Ivanin's fellow officers. ${ }^{8}$ For subsequent military historians, the 1839 disaster assumed a symbolic significance as a tragic, heroic sacrifice, which showcased Russian hardiness and endurance and enabled the

\footnotetext{
${ }^{5}$ Alison, History of Europe, Vol. X, pp. 1016-17; Kennedy, Rise and Fall, pp. 138-39; C.A. Bayly, The Birth of the Modern World 1780-1914 (Oxford, 2004) pp. 99, 112-13, 125-29. The Dutch, by contrast, were reluctant to think of themselves as imperialists because that was, by definition, an attribute of the 'Great Powers': $\mathrm{H}$. L. Wesselling 'The Giant that was a Dwarf, or the Strange History of Dutch Imperialism' in Andrew Porter and Robert Holland (eds) Theory and Practice in the History of European Expansion Overseas. Essays in Honour of R.E. Robinson (London: Frank Cass, 1988) pp. 58-70.

${ }^{6}$ See, most obviously, Edward Said, Orientalism. Western Conceptions of the Orient (London: Routledge \& Kegan Paul, 1978); see also C.A. Bayly, Empire and Information. Intelligence Gathering and Social Communication in India, 1780-1870 (Cambridge: Cambridge UP, 1996) pp. 143-49, 171-79, 315-17, 365-76.

7 Apart from the accounts by Dal', Ivanin, and Peslyak described below, see Anonymous, 'Voennoe Predpriyatie Protiv Khivu', Chteniya v Imperatorskom obshchestve istorii i drevnostei rossiiskikh pri Moskovskom Universitete (January-March 1860) Kn. 1 pp. 147-66; S. Zykov, 'Khivinskiya Dela s 1839-1842', Russkoe Slovo (March 1862) pp. 1-58; E.M. Kosyrev, 'Pokhod v Khivu v 1839 godu (Iz zapisok uchastnika)' IV No. 8 (1898) pp. 538-45.

${ }^{8}$ This was first published by Captain D. Golosov, who found the manuscript in the Orenburg archive and, not realising that the author was still alive and intended to publish it himself, sent it to the specialist military journal Voennyi Sbornik as his own work, although he had only added notes and a historical introduction: see M. Ivanin/D. Golosov, 'Pokhod v Khivu v 1839 godu otryada russkikh voisk, pod nachal'stvom General-Ad'yutanta Perovskago', Voennyi Sbornik [VS] No. 1 (1863) pp. 3-72; No. 2, pp. 309-58 and No. 3, pp. 3-71. On the article's publication, Ivanin alerted the editors of the journal, who published an explanation: 'Neobkhodimoe ob”yasnenie', VS No. 3 (1863) pp. 73-75. This account was then translated into English: Anonymous [Golosov/Ivanin], A Narrative of the Russian Military Expedition to Khiva under General Perofski, in 1839. Translated from the Russian for the Foreign Department of the Government of India (Calcutta: Office of the Superintendent of Government Printing, 1867). Ivanin published his own, revised version of the text a few years later: M. Ivanin, Opisanie Zimnego Pokhoda v Khivu v 1839-40g (St Petersburg: Tip. Tov. "Obshchestvennaya pol'za", 1874).
} 
4 A. Morrison 'Twin Imperial Disasters. The invasions of Khiva and Afghanistan in the Russian and British official mind, 1839 - 1842' Modern Asian Studies Vol.48 No.1 (2014) pp.253 - 300

army to learn important lessons that would render the later conquest of Central Asia possible. ${ }^{9}$ It was no coincidence that the first two volumes of Colonel A.G. Serebrennikov's enormous early twentieth-century collection of documents on the Russian conquest of Central Asia were largely devoted to the 'winter expedition to Khiva'. ${ }^{10}$ In the Soviet period, as a clear example of Russian aggression, it fitted poorly into the sanctioned narrative of 'prisoedinenie', the voluntary 'uniting' of Central Asia with Russia, and, when mentioned, it was usually considered a legitimate response to British machinations and aggression in Central Asia, especially the visits of Captain James Abbott and Lieutenant Richmond Shakespear to Khiva in 1839-40.11

The First Afghan War was a larger and more complex disaster, and the debates and recriminations surrounding it lasted at least until the generation of soldiers and politicians who were scarred by it had been laid to rest. It has also generated a voluminous historiography, and the narrative of what happened and the series of errors that led to the greatest British military humiliation of the nineteenth century, have long been clear. ${ }^{12}$ The chimerical nature of a Russian invasion of British India has also long been suspected: as Thomas Metcalf observed in his 1968 review of J.A. Norris's The First Afghan War, 'Until the Russian archives conclusively prove the contrary, the Russian threat must remain the product of an overheated imagination.' ${ }^{13}$ The relevant archives in Moscow have now been open for almost 20 years, and yet the unfashionable nature of diplomatic and military history for Western historians of the Russian empire, ${ }^{14}$ and the

9 The canonical versions are: I.N. Zakhar'in, Khiva. Zimnii pokhod v Khivu Perovskago v 1839 godu, - $i$ Pervoe posol'stvo v Kbivu'v 1842 godu (St Petersburg: Tip P. P. Soikina 1898), I.N. Zakhar'in, Graf V.A. Perovskii i ego zimnii pokhod v Khivu (St Petersburg: Tip. P. P. Soikina, 1901), which are not based on archival sources, but on oral accounts collected by the author from veterans in Orenburg in the 1890s, and M.A. Terent'ev, Istoriya Zavoevaniya Srednei Azii (St Petersburg: Tip. V. V. Komarova, 1906) Vol. I, pp. 92-172, the official history.

10 A.G. Serebrennikov, Sbornik Materialov dlya istorii zavoevaniya Turkestanskogo Kraya Vol. I: $1839 g$ (Tashkent: Tip. Shtaba Turkestanskogo Voennogo Okruga, 1908) and Vol. II: 1840g (Tashkent: Tip. Shtaba Turkestanskogo Voennogo Okruga, 1912).

${ }^{11}$ N.A. Khalfin, Rossiya i Khanstva Srednei Azii (pervaya polovina XIXv) (Moscow: "Nauka”, 1974) pp. $280-87$. See James Abbott, Narrative of a Journey from Heraut to Khiva, Moscow and St Petersburgh During the Late Russian Invasion of Khiva, with Some Account of the Court of Khiva and the Kingdom of Khaurism (London: W. H. Allen \& Co., 1843) 2 vols; and Richmond Shakespear, 'A Personal Narrative of a Journey from Heraut to Ourenbourg, on the Caspian [sic] in 1840', Blackwood's Edinburgh Magazine Vol. 51 (June 1842) pp. 691-720. ${ }^{12}$ The memoir literature associated with the First Afghan War is too voluminous to be listed here, but the originals of many of the most celebrated accounts have long been lost: William Trousdale, 'Dr. Brydon's Report of the Kabul Disaster and the Documentation of History', Military Affairs Vol. 47 No. 1 (February 1983) pp. 26-30. The omissions in the supposedly 'garbled' Blue Books of correspondence relating to Afghanistan published in 1839 were relatively innocent, although Kaye's re-edition of 1859 is more complete: G.J. Alder, 'The “Garbled” Blue Books of 1839-Myth or Reality?', The Historical Journal Vol. 25 No. 2 (1972) pp. 229-59. The historiography begins with Sir John Kaye, History of the War in Afghanistan (London, W. H. Allen \& Co, 1851, revised editions 1857 and 1874) 2 (3) vols. The most notable later contributions are: J.A. Norris, The First Afghan War 1838-1842 (Cambridge: Cambridge UP, 1967); M.E. Yapp, Strategies of British India. Britain, Iran and Afghanistan, 1798-1850 (Oxford: Oxford UP, 1980); Christine Noelle, State and Tribe in Nineteenth-century Afghanistan. The Reign of Amir Dost Mubammad Khan 1826-1823 (London: Curzon Press, 1997) pp. 38-53; B.D. Hopkins, The Making of Modern Afghanistan (Basingstoke: Palgrave Macmillan, 2008); Shah Mahmoud Hanifi, Connecting Histories in Afghanistan. Market Relations and State Formation on a Colonial Frontier (Stanford, California: Stanford UP, 2011) Chapter 3; and William Dalrymple, The Return of a King. The Battle for Afghanistan (London: Bloomsbury, 2013).

13 Thomas R. Metcalf, 'Review of J.A. Norris The First Afghan War 1838-42', The American Historical Review Vol. 74 No. 2 (December 1968) p. 614.

${ }^{14}$ D. Lieven, 'Introduction' in D. Lieven (ed.) The Cambridge History of Russia (Cambridge: Cambridge UP, 2006) Vol. II , p. 3. 
A. Morrison 'Twin Imperial Disasters. The invasions of Khiva and Afghanistan in the Russian and British official mind, 1839 - 1842' Modern Asian Studies Vol.48 No.1 (2014) pp.253 - 300

inability of most historians of South Asia to read Russian, mean that this question has still not been examined from the Russian perspective. ${ }^{15}$

In this paper I seek to adapt the concept of the 'official mind' developed by Ronald Robinson and John Gallagher in their pioneering study of the 'Scramble for Africa', and subsequently refined by other historians, to a comparison of two linked cases of early nineteenth-century imperial expansion. ${ }^{16} \mathrm{~A}$ central question facing any historian of the European empires is to understand why they expanded when they did. This question becomes all the more urgent when, as in these two cases, this expansion proved distinctly unprofitable, even damaging, to imperial aims. Strategic considerations, economic motives, personal ambition, local initiative, peripheral instability, and plain blundering can all have a role to play in determining imperial policy, but a crucial part of any analysis of the dynamics of expansion has to be an examination of the correspondence and memorandums of those who took the decisions, and an assessment of the individual personalities involved. ${ }^{17}$ As Zara Steiner puts it, 'documents are only stones in a complex mosaic'18 and the limitations of this approach are clear: it does not always distinguish clearly between motive and desired outcome, it cannot penetrate the subconscious wishes and fears of historical figures, and it must always take account of delusions and deceptions. The 'official mind' is not a single, coherent, omniscient, rational actor which carefully weighs up the available information and then makes a decision on the basis of its assessment of the national interest (and it is doubtful if Robinson and Gallagher would have recognized this description of their argument either). ${ }^{19}$ Still less is it Peter Cain and Anthony Hopkins' 'gentlemanly capitalist', making decisions on the basis of a narrower, but equally 'rational' calculation of the economic advantage that will accrue to an individual or his class (though Cain and Hopkins do not rule out motivations other than economic). ${ }^{20}$ Rather, the 'official mind' should be seen as a bundle of prejudices, assumptions, ambition, and ignorance, generally with very imperfect access to information, deeply affected by rumour, often reacting wildly and erratically to the pressure of 'events', and with multiple different identities and perspectives, of which Whitehall and St Petersburg were not necessarily the most important..$^{21}$

15 The exceptions are two valuable, if somewhat dated, articles: Philip Mosely, 'Russian Policy in Asia (1838-9)', Slavonic and East European Review Vol. 14 No. 42 (April 1936) pp. 670-681; and Mikhail Volodarsky, 'The Russians in Afghanistan in the 1830s', Central Asian Survey Vol. 3 No. 1 (1984) pp. $63-86$. Yapp made as much use as he could of such Russian archival material as had been published or preserved in British diplomatic correspondence in his magisterial Strategies, but he made some errors of interpretation. James L. Richardson, 'The Eastern Crisis 1839-1841' in J.L. Richardson Crisis Diplomacy. The Great Powers since the Mid-Nineteenth Century (Cambridge: Cambridge UP, 1994) pp. 37-68, ignores Afghanistan and Khiva altogether.

${ }^{16}$ R. Robinson and J. Gallagher with A. Denny, Africa and the Victorians. The Official Mind of Imperialism (London: Macmillan, 1961) pp. 19-26.

${ }^{17}$ T.G. Otte, 'Introduction: Personalities and Impersonal Forces in History' in T.G. Otte and Constantine A. Pagedas (eds) Personalities, War and Diplomacy. Essays in International History (London: Frank Cass, 1997) pp. 8-9.

18 Steiner, The Foreign Office, p. x.

${ }^{19}$ Eric Stokes, 'Bureaucracy and Ideology: Britain and India in the Nineteenth Century', Transactions of the Royal Historical Society Vol. 30 (1980) pp. 133-34.

20 P.J. Cain and A.G. Hopkins, British Imperialism. Innovation and Expansion 1688-1914 (London: Longman, 1993 ) pp. 42-52; Raymond Dumett 'Introduction' in Raymond E. Dumett (ed.) Gentlemanly Capitalism and British Imperialism. The New Debate on Empire (London: Longman, 1999) pp. 10-11 raised a similar query. ${ }^{21}$ Reynolds, Britannia Overruled, p. 57; Darwin, 'Imperialism and the Victorians', pp. 622, 640-42. 
6 A. Morrison 'Twin Imperial Disasters. The invasions of Khiva and Afghanistan in the Russian and British official mind, 1839 - 1842' Modern Asian Studies Vol.48 No.1 (2014) pp.253 - 300

The fact that British and Russian attitudes and decisions over Afghanistan and Khiva were so strikingly similar suggests that whatever the common factor in their decisions to expand into Central Asia was, it cannot have been wire-pulling by a new industrial bourgeoisie or a powerful class of gentlemanly financiers, as these did not exist in Russia. Dietrich Geyer's pioneering study of the links between Russian domestic and foreign policy does not cover the period before 1860 , but he concluded that even for the later period, when Russia had begun to industrialize, there is no evidence to suggest that economic interests played a role in the renewal of the advance into Central Asia after 1863: instead what mattered was the wider competition with Britain and a desire to restore prestige after defeat in the Crimean War. ${ }^{22}$ Equally, there is absolutely no evidence to suggest that British metropolitan financial or trade interests had any influence on the decision to invade Afghanistan, nor that they showed any desire to exploit it thereafter.

On the British side, debates regarding the annexation of Afghanistan and the development of trade along the Indus certainly were informed by contemporary ideas of political economy, which so many East India Company officials of that generation had imbibed at Haileybury. ${ }^{23}$ While the Russians also referred piously to the importance of trade, officials of both states saw it primarily as an instrument of policy, a means of projecting power by non-military means, and in both cases they had only the vaguest idea of what the real prospects for trade in Central Asia actually were. Economic theories of imperial expansion are thus of little relevance here. Of much greater importance are questions of institutional, and in particular military-bureaucratic, culture; 'Great Power' prestige; personal ambition (for honours and promotion, rather than better investment returns); growing European prejudice against 'barbarous Asiatics'; and the concomitant belief that they had the means and duty to spread 'civilization' in Asia. It is still sometimes argued even by Western scholars that Russian imperialism was qualitatively different from that of the West, owing to a sense of cultural and ethnic 'kinship' with Asians and a hybrid identity that lay midway between Europe and Asia. ${ }^{24}$ In this interpretation Russia is held to be largely free of the original sin of European 'Orientalism' or of a profound sense of difference from the Asian 'other'. ${ }^{25}$ This is a questionable argument, not because Russian culture always sought to separate itself from the 'Orient', but because the crude binary opposition proposed by Edward Said was not always true of the British or French empires either. ${ }^{26}$ It is of little relevance to an understanding of Russian official attitudes or state ideology, where a strong sense of 'Europeanness' and superiority to Asia predominated throughout most of the nineteenth

22 Dietrich Geyer, Russian Imperialism. The Interaction of Domestic and Foreign Policy, 1860-1914 (Leamington Spa: Berg, 1987) pp. 86-100. Local factors, of which Geyer was unaware, were also important, but these are beyond the scope of this paper.

${ }^{23}$ Alexander Burnes, 'On the Commerce of Shikarpur and Upper Scinde', Transactions of the Bombay Geographical Society, Vol. II (1836-38) (Bombay: American Mission Press, 1844) pp. 315-19; see further Eric Stokes, The English Utilitarians and India (Oxford: Clarendon Press, 1959) pp. 52-53, 81-93; Hopkins, Modern Afghanistan, pp. 38-39.

${ }^{24}$ See, for instance, Orlando Figes, Natasha's Dance. A Cultural History of Russia (Harmondsworth: Penguin, 2002) pp. 358-429; Mark Bassin, 'Geographies of Imperial Identity' in Lieven (ed.) Cambridge History of Russia Vol. 2, pp. 60-63.

${ }^{25}$ Nathaniel Knight, 'Grigor'ev in Orenburg, 1851-1862: Russian Orientalism in the Service of Empire?', Slavic Review Vol. 59 No. 1 (2000) pp. 74-100; S.N. Abashin, ‘Osobennosti Rossiiskogo Orientalizma’ in S.N. Abashin, D.A. Arapov and N.A. Bekmakhanova, Tsentral'naya Aziya v Sostave Rossiiskoi Imperii (Moscow: Novoe Literaturnoe Obozrenie, 2008) pp. 332-33.

${ }^{26}$ David Schimmelpenninck van der Oye, Russian Orientalism. Asia in the Russian Mind from Peter the Great to the Emigration (Newhaven, Connecticut: Yale UP, 2010) p. 194. 
A. Morrison 'Twin Imperial Disasters. The invasions of Khiva and Afghanistan in the Russian and British official mind, 1839 - 1842' Modern Asian Studies Vol.48 No.1 (2014) pp.253 - 300

century. ${ }^{27}$ Equally, that atavistic aggression, which Joseph Schumpeter identified as a legacy of aristocratic and absolutist continental imperialism in modern capitalist society, can in fact be just as well applied to the proconsuls of British India. ${ }^{28}$ These were all things that the British and the Russians had in common, and which helped to ensure that their default reaction to rumours of the other's expansion was to respond in kind.

\section{The Persian siege of Herat}

The roots of the crises of 1839, as has been long acknowledged, lay in Persia. In 1813, and again in 1828, Russia decisively defeated Fateh 'Ali Shah Qajar and annexed substantial territory in what is now Armenia and Azerbaijan. After the second of these victories, under the Treaty of Turkmanchai, Russia acquired a preponderant influence at the court of Tehran and established a permanent legation. The destruction of the Russian mission and the murder of Alexander Griboedov in 1829 were only a temporary setback to the growth of Russian power in Persia, since it was based on the presence of overwhelming military forces in Transcaucasia. ${ }^{29}$ These developments were viewed with growing alarm in London and Calcutta as a threat to Indian security, which had come to be seen as vital to sustaining Britain's status as the world's greatest power since the end of the Napoleonic wars. ${ }^{30}$ Muriel Atkin has argued that Russia's two successful wars with Persia were the product of accident rather than design, and were certainly not originally intended to form part of a drive towards India. ${ }^{31}$ In June 1832, Count K.V. Nesselrode (1780-1862), the Russian foreign minister, wrote to the new Russian envoy to Tehran, Count I.O. Simonich (1792-1855), stating that he believed the British had acquiesced to the terms of the Treaty of Turkmanchai and that he did not foresee any serious political differences emerging between Britain and Russia in Persia. ${ }^{32}$ This judgement turned out to be overly sanguine. As Russian trade spread through Mazandaran and Persian Azerbaijan, and the Qajars increasingly seemed to be doing Russia's bidding, disquiet continued to grow. By 1835, the surgeon to the British mission to Iran, Sir John McNeill (1795-1883), who would later become the official envoy, was convinced that by encouraging expansionist ambitions to the East (where Persia laid claim to sovereignty over the Afghan state of Herat) Russia was using Persia as a tool to threaten British India. ${ }^{33}$ In 1836, McNeill published an alarmist pamphlet, The Progress and

${ }^{27}$ Adeeb Khalid, Nathaniel Knight and Maria Todorova, 'Ex Tempore-Orientalism', Kritika Vol. 1 No. 4 (Fall 2000), pp. 691-727. Vladimir Bobrovnikov, 'Pochemu my marginaly? Zametki na poliakh russkogo perevoda “Orientalizma” Edwarda Saida', Ab Imperio No. 2 (2008), pp. 325-44; Alexander Morrison,

"Applied Orientalism” in British India and Tsarist Turkestan', Comparative Studies in Society and History Vol. 51 No. 3 (July 2009), pp. 619-47.

${ }^{28}$ Joseph Schumpeter, 'Imperialism and Capitalism' in Paul Sweezy (ed.) and Heinz Norden (trans.) Imperialism and Social Classes (Oxford: Oxford UP, 1951) pp. 83-85; Stokes, 'Bureaucracy and Ideology', pp. 146-56; C.A. Bayly Imperial Meridian. The British Empire and the World 1780 -1830 (London: Longman, 1989) pp. 106-07, 194-95, 248-56.

${ }^{29}$ Laurence Kelly, Diplomacy and Murder in Tehran. Alexander Griboyedov and Imperial Russia's Mission to the Shab of Persia (London: I. B. Tauris, 2002).

${ }^{30}$ Robinson and Gallagher, Africa and the Victorians, pp. 10-14.

${ }^{31}$ M. Atkin, Russia and Iran, 1780-1828 (Minneapolis, Minnesota: University of Minnesota Press, 1980) pp. 162-66.

${ }^{32}$ Nesselrode to Simonich, 7 June 1832, Akty, sobrannye Kavkazskoi Arkheograficheskoi Kommissii [AKAK] Vol. 8 No. 795 (Tiflis: Tip. Glavnogo Upravleniya Namestnika Kavkazskogo, 1881) p. 906; Volodarsky, 'The Russians in Afghanistan', p. 65.

33 The idea of Herat as the 'key to India' originated with Arthur Conolly, later to come to a sticky end at Bukhara. G.J. Alder, 'The Key to India?: Britain and the Herat problem 1830-1863', Middle Eastern Studies Vol. 10 No. 2 (1974) pp. 188-89. 
8 A. Morrison 'Twin Imperial Disasters. The invasions of Khiva and Afghanistan in the Russian and British official mind, 1839 - 1842' Modern Asian Studies Vol.48 No.1 (2014) pp.253 - 300

Present Position of Russia in the East, which did much to stimulate domestic Russophobia and had a considerable impact in the highest political circles. ${ }^{34}$ In 1837 , his fears appeared to have been fully realized when Muhammad Shah Qajar launched a military expedition against Herat, seemingly encouraged and abetted by Simonich, who accompanied the troops and was present throughout much of what would be a lengthy siege, giving credence to the idea that it was conducted with Russian support.

Debate has raged over whether Simonich exceeded his instructions from St Petersburg by encouraging the attack on Herat. Mikhail Volodarsky concludes that Nesselrode's later assurances that Simonich had defied instructions from St Petersburg were a lie, while Malcolm Yapp writes that Simonich was not responsible for encouraging the assault, but that, in giving a Russian guarantee to a treaty in which Muhammad Shah took the rulers of Kandahar under Persian protection, he had exceeded his brief. ${ }^{35}$ Simonich was a slippery character, and a careful examination of his correspondence and of a self-justificatory memoir written in 1841 does not provide a completely decisive answer to this question: nevertheless, some things are clear. First, that the original initiative to attack Herat came from Muhammad Shah himself; secondly, that Russian support for it was not of long standing; thirdly, that it was designed to protect what the Russians considered to be their legitimate trade interests in Persia and Central Asia, and not as the prelude to an attack on India; and, fourthly, that Simonich became quite conscious that his behaviour was provoking British paranoia on this issue, and that this was something the Russians could and should exploit.

The first assault on Herat in 1832-33 by 'Abbas Mirza, the heir to the throne, whom the Russians and the British alike were hoping would succeed his ailing father, Fateh 'Ali Shah, was certainly not encouraged by the Russians. ${ }^{36}$ Immediately after the withdrawal of Persian forces Simonich reported with dismay an interview at Zanjan with Khosro Mirza, 'Abbas Mirza's son, who stated that his father was planning to renew the attack: Simonich did his best to dissuade him, noting, 'The ease which they found last year appears to have turned their heads. ${ }^{37} \mathrm{He}$ added in a later despatch that he believed the expedition was a ploy by Fateh 'Ali Shah to keep his son and his Khorasani troops away from the capital. K.K. Rodofinikin (1760-1838), the head of the Asiatic Department, agreed with Simonich that 'Abbas Mirza's projects of conquest in Afghanistan spelled disaster for Persia if his father were to die during his absence. ${ }^{38}$ Russian hopes for 'Abbas Mirza were dashed after his death at Meshed in October 1833, and Simonich's opposition to an attack on Herat seems to have been largely bound up with the prince's fate. ${ }^{39}$ 'Abbas Mirza's death was followed shortly after by that of his father, Fateh 'Ali Shah, and the British and the Russians briefly combined forces to ensure the smooth succession of a different heir, Muhammad Shah Qajar. The latter revived plans to seize Herat in 1836: Yapp writes that even

\footnotetext{
34 Anon [J. McNeill], The Progress and Present Position of Russia in the East (London: John Murray, 1836); see Norris, First Afghan War, pp. 84-85, for an account of its impact.

35 Volodarsky, 'The Russians in Afghanistan', pp. 79-81; Yapp, Strategies, pp. 140-48.

${ }^{36}$ Hopkins, Modern Afghanistan, p. 63, erroneously suggests that Simonich 'advocated' the undertaking. ${ }^{37}$ Simonich to Nesselrode, 16 March 1833, Arkhiv Vneshnei Politiki Rossiiskoi Imperii [AVPRI], Fond [F.] 133, 'Kantselyariya Ministra Inostrannykh Del' Opis' [Op.] 469 1833g. Delo [D.] 208, 'Téhéran (Dépêches du Comte Simonitch)' 1l. (ff.) 25ob-6.

${ }^{8}$ Simonich to Nesselrode, 7 April 1833; Rodofinikin to Simonich, 14 February 1833, AVPRI, F.133, Op.469 1833g. D.208 1l.36, 209ob; 'Abbas Mirza was hostile to the British, but both powers saw his smooth succession as the key to political stability in Persia.

${ }^{39}$ Simonich to Rozen, 11 November 1833, AKAK Vol. 8 No. 811, p. 915.
} 
then Simonich was trying to discourage this, and that his subsequent decision to accompany the Persian forces was because he was anxious to bring a group of Russian deserters serving in the Persian army into custody..$^{40}$ Simonich was initially sceptical, particularly when Muhammad Shah proposed leading the troops himself: this was partly because of the personal inconvenience he foresaw, and also because, at this stage, he thought the campaign had scant chance of success. ${ }^{41}$ When later asking for permission to attend the siege, he did indeed state that this was because his personal intervention was needed to reassure the Russians in the Shah's service that they would not be punished for desertion. ${ }^{42}$ However, his opinion rapidly changed once he saw how the British responded to the proposed Herat expedition. In April 1836 he wrote to Nesselrode that, 'If I take it so much to heart to see these projects succeed, it is precisely because the English are opposing them with all their means. ${ }^{33}$ At this stage he claimed to be unaware of why the proposed invasion seemed to worry the British so much: six weeks later, in what was apparently a personal letter to Rodofinikin, he wrote: 'Naturally I asked myself what reasons guide England in this minute surveillance of the military establishments of Persia... What are they afraid of? Their precarious situation in India.' His claim that it was only in the previous few days that he had realized that this was the cause of English jumpiness was probably disingenuous, but, having prepared the ground with his superiors, he now offered this both as an example of how the English misjudged Russia, and also as a diplomatic opportunity to be exploited. ${ }^{44}$ In his later memoir he wrote that Persia had become a 'spectre' that robbed the London cabinet of rest, as they interpreted the simplest events as a putative attack on India. ${ }^{45}$

However, Simonich's satisfaction at having rattled the British rapidly turned to fear once he received confirmation of rumours that they had responded by sending an envoy to Afghanistan, and he melodramatically foresaw the complete eclipse of Russian power in Central Asia.

Simonich argued for the creation of a powerful Afghan buffer state under Persian suzerainty and Russian protection to counter this threat, something he attempted to bring about himself by undertaking, on his own authority and initiative, to guarantee a treaty between Muhammad Shah and the Sardars of Kandahar. ${ }^{46}$ Simonich did not deny that he had exceeded his brief somewhat, but justified it in terms that reveal an overweening ambition and sense of self-importance: '[Any] minister of Russia, sought out on both sides, finding himself in such favourable circumstances, and able with the stroke of a pen to render his nation the arbiter of the Orient—would he not have profited from such a fine occasion? I gave the guarantee. ${ }^{97}$ In August 1837 Simonich was removed from his post in Tehran, but it is not clear whether this was because St Petersburg thought he had been insubordinate or because Simonich himself was anxious to rejoin his wife

\footnotetext{
${ }^{40}$ Yapp, Strategies, pp. 144-46.

${ }^{41}$ Simonich to Nesselrode, 10 January 1836, AVPRI, F.133 Op.469 1836g. D.204, 'Dépêches recues de Téhéran en 1836 (Cte. Simonich)' 11.8-10ob.

42 Simonich to Rozen, 15 January 1836; Simonich to Rodofinikin n.d. (December 1837), $A K A K$ Vol. 8 No. 861 and No. 900, pp. 937, 957-58.

${ }^{43}$ Simonich to Nesselrode, 3 April 1836, AVPRI, F.133, Op.469 1836g. D.204 1.79ob.

44 Simonich to Rodofinikin, 20 April 1836, AVPRI, F.133, Op.469 1836g. D.204 1l.153-4.

${ }^{45}$ I.O. Simonich, 'Précis historique de l'Avénement de Mahomed-Schah au Trone de Perse par le Comte Simonich, ex-Ministre plénipotentiaire de Russie à la cour de Téhéran. Varsovie, l'année 1841', pp. 359-61, Sankt Peterburgskii Filial Institut Vostokovedenie RAN, Arkhiv Vostokovedov [AV], 1-i Razryad [R.] Op.6 D.1 1.24 .

${ }^{46}$ Simonich to Nesselrode, 13 October 1836, AVPRI, F.133, Op.469 1836g. D.204 1.258ob.

${ }^{47}$ Simonich, 'Précis historique', pp. 359-61, AV, 1-i R. Op.6 D.1 1.190.
} 
10 A. Morrison 'Twin Imperial Disasters. The invasions of Khiva and Afghanistan in the Russian and British official mind, 1839 - 1842' Modern Asian Studies Vol.48 No.1 (2014) pp.253 - 300

(the beautiful Princess Orbeliani) and their ten children in Tiflis. ${ }^{48} \mathrm{He}$ was replaced by A.O. Duhamel (1801-1880), the former Russian envoy to Egypt. Contrary to Mosely's suggestion, Duhamel does not appear to have been explicitly instructed to repudiate Simonich's guarantee of the treaty with the Sardars of Kandahar. ${ }^{49} \mathrm{He}$ did not arrive in Tehran until September 1838, and while still en route he sent repeated requests to Nesselrode asking for a decision on the matter, himself advocating further support for the Afghan ruler of Kabul, Dost Muhammad Khan, against British aggression. In December 1838 he wrote:

... some sort of decision is no less urgent, indispensable, if we do not wish to lose the credit in which we currently rejoice in Asia... if after all this we today abandon the Barakzai brothers to the vengeance of their enemies, believe me, M. le Comte, that the Russian name will suffer a taint, which centuries will not suffice to efface, in the opinion of the peoples of Central Asia: a retrograde step will be considered as a sign of weakness. ${ }^{50}$

This fear of being perceived as weak by 'Asiatics' was a recurring theme in all Russian thinking on Central Asia over the course of the nineteenth century, and here it was compounded by a fear that they were losing ground to the British. In 1839 it became clear that the British were going to invade Afghanistan, and at this stage the hollowness of Russia's pretensions to be able to give direct assistance to Dost Muhammad were clearly revealed. Nesselrode chose to present this to the tsar as a case of Asiatic cunning and intrigue, writing that Simonich had been used as a tool by Dost Muhammad and the Sardars of Kandahar, and he launched a diplomatic rapprochement with Britain in an unsuccessful attempt to avert the invasion. ${ }^{51}$ The former envoy became the scapegoat, condemned for having provoked the British invasion of Afghanistan, which, until the disasters of 1842, the Russians believed to have been a success, permanently establishing British power in Central Asia to their detriment. Duhamel, carefully eliding his own earlier advocacy of Russian intervention in Afghanistan, wrote:

In the expedition against Herat, the English believed they saw the beginning of projects long planned between Russia and Persia for the conquest of India... Unfortunately one cannot deny that the comments and all the conduct of Count Simonich was of the nature to give credit to this erroneous opinion. ${ }^{52}$

\footnotetext{
48 Simonich to Nesselrode, 14 June 1836, AVPRI, F.133, Op.469 1836g. D.204 1.139; I.F. Blaramberg, Vospominaniya (Moscow: "Nauka", 1978) p. 97.

${ }^{49}$ Mosely, 'Russian Policy in Asia', p. 670.

${ }^{50}$ Duhamel to Nesselrode, 1 September 1838; Duhamel to Nesselrode, 23 December 1838 (Draft), AVPRI F.194 'Missiya v Persii' Op. 528/1 D.182 ‘za 1838g.' ll.3ob, 58ob, 59ob. Characteristically, Duhamel disguised this in his memoirs, claiming that on his arrival he had immediately taken steps to repudiate Simonich's actions and establish better relations with Britain: 'Avtobiografiya A.O. Diugamelya', RA, Vol. 5 Kn.2 (1885) pp. 104-05.

${ }^{51}$ Nesselrode to Nicholas I, 'Rapports a l'Empereur, 1839' in Mosely, 'Russian Policy in Asia', pp. 675-77; Harold N. Ingle, Nesselrode and the Russian Rapprochement with Britain, 1836-1844 (Berkeley, California: University of California Press, 1976) pp. 72-95.

${ }^{52}$ Duhamel to Nesselrode, 22 November 1841, AVPRI, F.133, Op.469 1841g. D.213 'Téhéran (Affaires de l'Asie)' 11.451ob-2. Duhamel would later claim that Simonich was dismissed for insubordination, and he did his best to discredit him, writing that he was a 'Bonapartist' (Simonich was of Dalmatian origin and had been captured while serving with Napoleon in 1812, entering Russian service on his release) and that he got on so badly with McNeill that, had he remained in post a year longer, it would have led to open war with Britain. 'Avtobiografiya A.O. Diugamelya', pp. 84-91; Blaramberg, Vospominaniya, p. 97.
} 
A. Morrison 'Twin Imperial Disasters. The invasions of Khiva and Afghanistan in the Russian and British official mind, 1839 - 1842' Modern Asian Studies Vol.48 No.1 (2014) pp.253 - 300

Simonich himself was unrepentant, and considered that a golden opportunity to knock back the British in Central Asia had been lost: 'the fate of India was in our hands'. ${ }^{33}$ In fact, within a few months the Anglo-Sadozai regime in Kabul would fall, and the longer term significance of the British reaction to the siege of Herat would be clear-namely, that it was one of the factors that had caused them to overreach themselves disastrously in Afghanistan.

\section{The British and Russian missions to Afghanistan}

British policy on the Indian empire's northwest frontier in this period has been the subject of exhaustive study over the last 50 years: Edward Ingram concluded that countering the Russian threat on a global scale was the paramount concern, ${ }^{54}$ and Yapp that significant disagreement existed between different 'schools' of frontier policy, but that they were more narrowly concerned with the defence of India itself. Most recently, as part of a (very welcome) attempt to escape the stranglehold which the so-called 'Great Game' has exercised on the Anglophone historiography of Central Asia and give local actors their proper due, Benjamin Hopkins has argued that the British were much more concerned with the potential threat from Ranjit Singh and the Sikh Khalsa—and with the power of rumour to destabilize their rule in India—than they were with the distant Russian menace. ${ }^{55}$ None of these arguments is wholly satisfactory, largely because to escape from the preoccupations found in British documents, as advocated by Hopkins, one needs to find alternative sources — either in Russian or Persian-which none of these authors has managed to do. The fact that the British feared that mere rumours of a Russian advance might be sufficient to threaten the East India Company, even without an actual invasion, was certainly the case and Hopkins' suggestion that the emphasis on the Russian threat reflected a bureaucratic need for a recognizable and comprehensibly European opponent is intriguing (if, in my view, unproven, particularly given the British tendency to characterize the Russians as oriental and inscrutable). Although he is quite correct that various parties emphasized the Russian menace in official correspondence in order to push forward an expansionist agenda, the suggestion that this obscured a more profound fear of Ranjit Singh is less convincing: the evidence presented by Hopkins himself suggests that, while Sikh ambitions in Sind and towards Peshawar were a cause of concern, it was only after Ranjit Singh's death in the summer of 1839 that the Anglo-Indian leadership really began worrying about political instability in the Punjab and the danger posed by a leaderless Khalsa. ${ }^{56}$ Yapp has shown convincingly how, after some debate, by 1837 Lord Auckland (1784-1849), the governor-general, had decided that the East India Company's alliance with the Sikh ruler was the key to British security. Nothing could be allowed to compromise this, least of all the interests of the amirs of Sind and the Barakzai rulers of Afghanistan, chief among whom (although it took a while for Auckland to realize this) was Dost Muhammad Khan at Kabul, who had deposed the Sadozai ruler Shah Shuja ul-Mulk in 1809. Dost Muhammad deeply resented the seizing of Peshawar from his brother, Sultan Ahmad Khan, by the Sikhs in 1833, at a time when he had been distracted by an unsuccessful attempt by Shuja ul-Mulk to regain his throne (with, so the Barakzais suspected, covert British support). ${ }^{57}$

\footnotetext{
53 'le sort des Indes était en nos mains': Simonich, 'Précis historique', pp. 360-61, AV, 1-i R. Op.6 D.1 11.193-4.

${ }^{54}$ Edward Ingram, In Defence of British India: Great Britain in the Middle East, 1775-1842 (London: Frank Cass, 1984) pp. 130-217.

55 Hopkins, Afghanistan, pp. 34-47.

${ }^{56}$ Hopkins, Afghanistan, p. 67.

${ }^{57}$ On the complex dynastic and tribal politics of Afghanistan before Dost Muhammad's accession in 1826, see Noelle, State and Tribe, pp. 1-14. By far the most vivid portrait of Shah Shuja in English is to be found
} 
12 A. Morrison 'Twin Imperial Disasters. The invasions of Khiva and Afghanistan in the Russian and British official mind, 1839 - 1842' Modern Asian Studies Vol.48 No.1 (2014) pp.253 - 300

Dost Muhammad's failure to obtain any kind of redress from the British at the time, together with the Persian threat to his western frontier, had prompted him to make approaches both to them and to the Russians.

This was the political background to Captain Alexander Burnes's (1805-1841) mission to Kabul in autumn 1837. Burnes was visiting Afghanistan for the second time, having passed through Kabul in 1831 on his celebrated journey to Bukhara, when he was accompanied by his Kashmiri secretary, Mohan Lal. ${ }^{58}$ He was not the first British 'expert' on Afghanistan: that distinction belonged to John Lewis, better known as Charles Masson, a deserter from the Company's army who became a newswriter in Kabul and whose (unacknowledged) advice and assistance had been crucial to Burnes's introduction to Kabuli society six years earlier. ${ }^{59}$ Burnes's brief on this occasion was to resolve the dispute between the Afghans and the Sikhs, and to draw up a commercial treaty, but he rapidly exceeded his remit. The reappearance of a British agent at Kabul encouraged the amir to believe that some sort of restitution of Peshawar might be possible in return for an alliance with the British. This was also the policy advocated by Burnes himself, in direct contradiction of what he knew to be his superiors' views and the ostensible purpose of his mission. In October 1837 he was already boasting to his friend Captain G.L. Jacob at Rajkot that he had abandoned commercial negotiations in favour of political intrigue, and was about to arrange an alliance with Dost Muhammad and a Sikh withdrawal from Peshawar in return for Afghan tribute. ${ }^{60}$

Burnes would soon discover his error - the government of India had no intention of putting pressure on Ranjit Singh to withdraw from Peshawar, and Dost Muhammad had no intention of paying tribute to a non-Muslim ruler. All parties made severe misjudgements_-Dost Muhammad had exaggerated expectations of what the British would offer, Burnes exaggerated the Russian threat and went far beyond what Calcutta was prepared to support, while Auckland misunderstood Dost Muhammad's position, thinking that he feared further attacks from the Sikhs, and greatly overestimated the value of a British alliance to the Afghan ruler. ${ }^{61}$

Three factors helped to raise the stakes in Afghanistan and convince the British that there was a real danger of Russian influence being established within a few hundred miles of their Indian frontier. The first, as we have seen, was the Persian attack on Herat in 1837. The second was the preparation of a punitive Russian expedition to Khiva, and the third was the dramatic arrival in Kabul of a Russian envoy, Captain Ivan Viktorovich Vitkevich (1809-1839) of the Orenburg

in Dalrymple, Return of a King, pp. 1-73. See also Shah Mahmoud Hanifi, 'Shah Shuja's "Hidden History" and its Implications for the Historiography of Afghanistan', South Asia Multidisciplinary Academic Journal 14 May 2012: < http://samaj.revues.org/3384> , [accessed 17 May 2013].

58 Alexander Burnes, Travels into Bokhara, Being the Account of a Journey from India to Cabool, Tartary and Persia (London: John Murray, 1834) 3 vols; Mohan Lal, Travels in the Punjab, Afghanistan, \& Turkistan, to Balk, Bokhara and Herat (London: W. H. Allen \& Co., 1846).

${ }^{59}$ Masson never achieved the same celebrity as Burnes, and his policy influence was negligible, but he was acknowledged as a pioneering archaeologist and numismatist who carried out some of the earliest research on Afghanistan's pre-Islamic past: see H.H. Wilson, Ariana Antiqua. A Descriptive Account of the Antiquities and Coins of Afghanistan. With a Memoir of the Buildings called Topes, by C. Masson (London: Published under the authority of the Honourable the Court of Directors of the East India Company, 1841) pp. v-xii; Hopkins, Afghanistan, pp. 16-17, 44-45.

${ }^{60}$ Burnes to Jacob, 29 October 1837, National Archives of India [NAI]/Foreign/S.C./28 September 1842/Nos. 33-42 Sir Alexander Burnes' correspondence regarding the disaster at Cabul, pp. 7-8.

${ }^{61}$ For a detailed description, see Yapp, Strategies, pp. 224-40, and Hopkins, Afghanistan, pp. 64-65. 
A. Morrison 'Twin Imperial Disasters. The invasions of Khiva and Afghanistan in the Russian and British official mind, 1839 - 1842' Modern Asian Studies Vol.48 No.1 (2014) pp.253 - 300

Cossacks, just a few weeks after Burnes. This prompted the latter to write to his brother-in-law, Major James Holland, in great excitement:

We are in a mess here. Herat is besieged and may fall, and the Emperor of Russia has sent an envoy to Cabool to offer Dost Mahomed Khan money to fight Runjeet Singh!!!!! I could not believe my eyes or ears, but Captain Vickovitch [sic], for that is the agent's name, arrived here with a blazing letter three feet long, and sent immediately to pay his respects to myself; I of course received him, and asked him to dinner. ${ }^{62}$

In his official report to Lord Auckland, Burnes also referred to 'This dazzling specimen of caligraphy [sic]'. ${ }^{63}$ The file on the Vitkevich mission in the Russian Imperial Foreign Policy Archive contains neither the original (which presumably remained with Dost Muhammad) nor even a copy of the text of this magnificent document, but judging from the translation (from Russian via Persian into English), which Burnes forwarded to Auckland, it was formal and fairly innocuous. The letter to Dost Muhammad from Simonich caused more misgivings, as he had written: 'I hope that on his [Vitkevich's] arrival at your Court you will treat him with consideration, and trust him with your secrets. ${ }^{94}$ Although Burnes was initially suspicious of Vitkevich's credentials, he subsequently wrote to Calcutta that he was sure that the envoy was who he professed to be and had full authority to negotiate at Kabul. ${ }^{65}$ Nevertheless there have been suggestions that Simonich exceeded his instructions in writing to Dost Muhammad, and that Vitkevich's mission was unauthorized. Given how large this mission has tended to loom in British accounts of the origins of the First Afghan War as evidence of the reality of the Russian threat, it requires more detailed examination from a Russian perspective.

In a statement to the Asiatic committee in May 1835, Nesselrode had attempted to lay out the correct response to the emissaries Russia had been receiving from India and Afghanistan requesting assistance in fighting off English aggression. While acknowledging the benefits that would accrue were Russia to extend friendly trade relations in the region, Nesselrode added that: 'entering into relations with Afghanistan and India must be done with care and extreme circumspection, in order not to excite the habitual distrust of foreigners, and in particular the English Government'. ${ }^{66}$ Although exchanges of presents and trade agreements could be authorized, there could be no guarantees of protection or support. In May 1836 this policy was tested by the arrival in Orenburg of Hussain 'Ali, an envoy from Dost Muhammad Khan,

\footnotetext{
${ }^{62}$ Burnes to Holland, 9 January 1838. G. Buist, 'Memoir of Sir Alexander Burnes, C.B.' in James Burnes, Notes on his Name and Family (Edinburgh: Printed for private circulation, 1851) pp. 56-57. Burnes barely mentions Vitkevich in his posthumous memoir Cabool: a Personal Narrative of a Journey to and Residence in That City (London: John Murray, 1842) pp. 143, 261-62, but the Russian agent figures prominently in his official and unofficial correspondence.

${ }^{63}$ Burnes to Auckland, 23 December 1837, 'East India (Cabul and Affghanistan). Copies of the Correspondence of Sir Alexander Burnes with the Governor General of India, during his Mission to Cabul in the Years 1837 and 1838, or such part thereof as has not already been published', Parliamentary Papers [PP] Vol. XXV.7 No. 1 (8 June 1859) p. 90.

${ }^{64}$ Burnes to Macnaghten, 22 December 1837, Enclosures 2 and 4 PP Vol. XXV.7 No. 1 (8 June 1859) pp. 85-86.

${ }^{65}$ Burnes to Macnaghten, 22 January 1838, PP Vol. XXV.7 No. 1 (8 June 1859) p. 91.

66 'O poslannikakh iz Afganistana i Indii', 27 May 1835, AVPRI, F.161 (St Petersburg Gl. Arkh.) I-1 Op.781 D.75 11.32-33ob.
} 
14 A. Morrison 'Twin Imperial Disasters. The invasions of Khiva and Afghanistan in the Russian and British official mind, 1839 - 1842' Modern Asian Studies Vol.48 No.1 (2014) pp.253 - 300

accompanied by Vitkevich, who had met him while on a mission to Bukhara. Hussein 'Ali bore letters to the tsar and the governor of Orenburg, V.A. Perovsky (1794-1857) which appealed to Russia to grant him the same degree of support as that which the Persian government now enjoyed, to enable him to counter the Sadozais, the Sikhs, and the British. ${ }^{67}$ Perovsky was the central figure in Russian policy towards Central Asia in the first half of the nineteenth century: the illegitimate (but acknowledged) son of one of Russia's greatest magnates, Count A.K. Razumovsky, he was a hero of the Napoleonic Wars (where he had been wounded at Borodino) and was ennobled in his own right by Alexander I. He had a close personal relationship with Nicholas I, whom he had accompanied on his educational tours around Russia and Europe before his accession, and whom he had personally protected on St Isaac's Square during the Decembrist Revolt. ${ }^{68}$ As such, his views carried considerable weight in St Petersburg, and he did not doubt that this represented a golden opportunity to halt what appeared an unstoppable English advance in Central Asia:

If Shah Shuja ul-Mulk seizes Afghanistan then the country will be entirely subject to the East India Company and the English will be left just a step away from Bukhara itself-and all Central Asia will be in their hands. Our Asian trade will collapse and... the English will encourage the neighbouring Asian lands against us and will supply them with munitions, weapons and money, and this is all that is wanting to transform our negligible opponents into dangerous foes... The English maintain their devotees, or those whom they have bought, not only in Kabul, but even in Bukhara itself. They act against us; use every circumstance in order to harm us and our trade, and in order to oppose them it is necessary to pay in the same kind of coin. ${ }^{69}$

Rodofinikin, the head of the Asiatic Department, was not quite so eager to embroil Russia in the affairs of Kabul. He expressed doubts about Hussain 'Ali's credentials, citing two previous envoys from Dost Muhammad and a bogus envoy from Lucknow called Kafayet Khan who had turned up in Tiflis the year before, escorted by Simonich, who accepted his bona fides, but whom Rodofinikin claimed had been sent by the English as a spy. ${ }^{70}$ What also troubled him was that Hussain 'Ali had been in Russia before, when he accompanied a refugee Sadozai prince called Shahzada Farrukh to Orenburg, a circumstance Rodofinikin thought rather suspicious: ${ }^{71}$ he seems to us rather strange and wonderful: how can the Khan of Kabul [sic] have decided to send

${ }^{67}$ Amir Dost Muhammad Khan Ghazi to Emperor Nicholas I and to Count V.A. Perovsky, translated from the Persian (late October 1835, no original), AVPRI, F.161 'Sankt-Peterburgskii Glavnyi Arkhiv' I-5 Op.5 D.2. Although Volodarsky cites much other valuable material from AVPRI, he does not appear to have consulted this file: 'O priezde v S-Peterburge Kabulskogo Poslannika Gussein Ali, tut zhe ob otpravlenii Poruchika Vitkevicha v Kabul dlya vstupleniya v blizhaishiya snosheniya s Avganistanom’ ll.10ob, 12-13. A version of the same letter reached Burnes from a newswriter in Bukhara and was sent on in translation to Calcutta: PP Vol. XXV.7 No. 1 (8 June 1859) p. 85.

68 'Graf Vasilii Alekseevich Perovskii', RA, No. 3 (1878) pp. 373-74.

${ }^{69}$ Perovsky to Nesselrode, 5 May 1836, AVPRI, F.161 I-5 Op.5 D.2 11.7-8.

${ }^{70}$ Simonich to Nesselrode, 31 May 1835, AVPRI, F.133 Op.469 1834-5g. D.237 1.191ob; Simonich to Nesselrode, 30 January 1835; Simonich to Rodofinikin, 12 July 1835, AVPRI, F.194 Op.528a D.158 11.4-5, 47-ob.

71 This was in 1831, when Shahzada Farrukh arrived in Orenburg from Khiva requesting permission to travel on to St Petersburg, and was politely turned away with a present of money by Governor Sukhtelen. Shahzada Farrukh to Sukhtelen, 16 August 1831; Sukhtelen to the Ministry of Foreign Affairs, 19 August 1831, AVPRI, F.161 I-7 Op.6 D.1 1l.11-12ob, 15-18ob in N.E. Bekmakhanova (ed.) Prisoedinenie Kazakhstana i Srednei Azii k Rossii (XVIII-XIX veka). Dokumenty (Moscow: RAN, 2008) Documents 31 and 32, pp. 118 22. 
him to Russia, when he could not have been unaware that he had visited us before with a prince of that very dynasty which he overthrew? ${ }^{72}$ Rodofinikin also thought the tone of the letters unusually subservient for an Asiatic monarch. Perovsky disagreed, insisting that the letters from Dost Muhammad were genuine, and that he had probably chosen Hussain 'Ali because of his previous familiarity with the Russians, while the subservient tone reflected the immense pressure the amir was under. In this, as in most other aspects of the Afghan mission, Perovsky's views prevailed. Hussain 'Ali was granted a passport and allowed to proceed to St Petersburg, where Rodofinikin interviewed him personally. ${ }^{73} \mathrm{He}$ would be accompanied by the same young, newly promoted Cossack officer who had brought him to Orenburg from Bukhara, an exiled Polish nobleman called Jan Prosper Witkiewicz (Russified to Ivan Vitkevich) who had become Perovsky's unlikely protégé.

Vitkevich is an intriguing, enigmatic figure. He was exiled from Vilna in 1822 at the age of 14, together with five schoolmates from the gymnasium, one of whom, Peslyak, later recorded his experiences in a short memoir (which, together with the reminiscences of the military topographer I.F. Blaramberg, constitutes our principal source for his biography). Their crime was membership of a 'revolutionary-national' organization called the 'Black Brothers': two of the other accused were sentenced to death, and although this was commuted to imprisonment, one died mad in gaol. Vitkevich was sent to serve as a private soldier in Orsk, and the remaining three to different steppe fortresses. Here they were placed under harsh military discipline and forbidden to write letters, even to their families. ${ }^{74}$ Where Peslyak sought solace in natural history, teaching children how to read, giving dancing classes, and learning how to make shoes and boots, Vitkevich devoted himself to learning oriental languages and understanding the steppe culture that surrounded him. In 1829 he had a well-known encounter with the German natural philosopher Alexander von Humboldt, at that time carrying out geographical researches for the Russian government, who was amazed to find a complete collection of his works in the young soldier's quarters, and to whom Vitkevich is supposed to have confided a plan to escape from Orenburg across the steppe to India. Notwithstanding this apparent indiscretion, under Governor Sukhtelen, Vitkevich was promoted to officer cadet and appointed a translator with the Orenburg frontier commission. He seems to have attracted Perovsky's attention immediately after the latter took up his post as governor of Orenburg in 1833: soon Vitkevich had been commissioned as an ensign and sent on a mission to Bukhara, from which he returned with accurate information and maps of his route which apparently earned him an audience with the tsar. ${ }^{75}$ It was unsurprising then that Perovsky wrote to Nesselrode in 1836 to say that Vitkevich had more than made up for his youthful political mistakes at the Vilna gymnasium, and that he would be the ideal person to accompany the Afghan ambassador and act as his translator, first in

\footnotetext{
${ }^{72}$ Rodofinikin to Perovsky, 13 July 1836, AVPRI, F.161 I-5 Op.5 D.2 11.36-9; Simonich was told by an informant from Herat that Hussain 'Ali had actually entered Russian service in Orenburg for a time. Simonich to Rodofinikin, 5 September 1836, AVPRI, F.133 Op.469 1836g. D.204 l.165ob.

${ }^{73}$ Perovsky to Rodofinikin, 4 August 1836; Rodofinikin to Vitkevich (n.d.), AVPRI, F.161 I-5 Op.5 D.2 11.46-7, 63 .

${ }^{74}$ Aloizii Peslyak, 'Zapiski Peslyaka', IV No. 9 (1883) pp. 577-78; Blaramberg writes that Vitkevich was 17 when he was exiled from the Warsaw gymnasium, but he only met Vitkevich as an adult and presumably heard these stories second-hand: Blaramberg, Vospominaniya, p. 85.

75 Peslyak, 'Zapiski', pp. 584-85; Blaramberg, Vospominaniya, pp. 85-86; Vitkevich's account of this mission was eventually published as 'Zapiska, sostavlennaya po rasskazam Orenburgskogo Lineinoga Batal'ona No. 10 Praporshchika Vitkevicha otnositel'no puti ego v Bukharu i obratno' in N.A. Khalfin (ed.) Zapiski o Bukharskom Khanstve (Moscow: "Nauka", 1983).
} 
16 A. Morrison 'Twin Imperial Disasters. The invasions of Khiva and Afghanistan in the Russian and British official mind, 1839 - 1842' Modern Asian Studies Vol.48 No.1 (2014) pp.253 - 300

St Petersburg, and then on the return journey to Kabul via Persia. ${ }^{76}$ However, Hussain 'Ali fell ill in Moscow, and although he eventually reached Tiflis and was sent on from there by Baron Rozen to Tabriz and Tehran, he does not appear to have reached Afghanistan. ${ }^{77}$ Vitkevich instead took charge of the tsar's official letter to Dost Muhammad, and Nesselrode authorized him to continue alone to the Caucasus (where he met Blaramberg, who accompanied him as far as Tabriz) and then on through Persia to Kabul. ${ }^{78}$ His instructions from Nesselrode indicated that it would be up to Simonich to decide whether to send him on to Kabul or not, depending on the political situation. If he were to carry on, then he was to urge the Afghan rulers of Kabul and Kandahar to unite in a strong confederation to resist the British, but without making any offer of direct assistance..$^{79} \mathrm{He}$ was also told to try to reach a trade agreement, to encourage Afghan merchants to travel to the great fair at Nizhny Novgorod, and to gather as much information as possible about Afghanistan and the relations of its rulers with the British. In Tehran he met Simonich and may have received further, verbal instructions from him: Simonich himself later claimed that he had simply repeated St Petersburg's orders, although, had he told Vitkevich to give assurances of Russian military support, he would have been unlikely to admit it. ${ }^{80}$ From Tehran Vitkevich proceeded first to the royal encampment at Herat, where he had an audience with Muhammad Shah, before continuing to Kandahar and Kabul, where his appearance so startled Burnes. ${ }^{81}$

Hereafter Vitkevich's story is incomplete, as the documents relating to his embassy to Afghanistan include only the most formal communications from him concerning his whereabouts, together with inaccurate reports that he had left Afghanistan for Khiva and been killed there (in fact, he returned safely to the Russian encampment at Herat in June 1838, accompanied by the son of one of the rulers of Kandahar). ${ }^{82}$ On 9 May 1839, shortly after returning to St Petersburg, Vitkevich shot himself in his room at the Hotel 'Parizh', having first supposedly burned all the notes and materials he had brought back with him from Afghanistan. ${ }^{83}$ As L.G. Senyavin (1805-1861), the new director of the Asiatic Department, noted in a personal letter to Perovsky shortly afterwards: 'In a word, with him perished all the information about Afghanistan which would now be particularly precious and useful to us. Only what he managed to relate to me about it is known. ${ }^{84}$ As it is, the file on Vitkevich's mission contains just four

\footnotetext{
${ }^{76}$ Perovsky to Nesselrode, 5 May 1836, AVPRI, F.161 I-5 Op.5 D.2 1.8ob. Strangely Peslyak does not refer to Vitkevich's embassy to Afghanistan, writing that he remained in Tehran for three years: Peslyak, 'Zapiski', p. 585.

${ }_{77}$ Rozen to Nesselrode, 10 November 1837, AKAK Vol. 8 No. 891 p. 953.

${ }^{78}$ Rodofinikin to Vitkevich, Nesselrode to Simonich, 14 May 1837, AVPRI, F.161 I-5 Op.5 D.2 11.71-4; Blaramberg, Vospominaniya, pp. 87-96.

79 'Instruktsiya Poruchik Vitkevichu, ot 14-ogo Maya 1837 goda No. 1218', AKAK Vol. 8 No. 874 pp. $944-$ 45.

${ }^{80}$ Simonich, 'Précis historique', pp. 342, 347, AV 1-i R. Op.6 D.1 1l.174ob, 187ob; Volodarsky, 'The Russians in Afghanistan', pp. 75-76.

${ }^{81}$ Vitkevich to Simonich, 9 October 1837, AVPRI, F.194 Op. 528a D.131 'O Vitkeviche v delakh Afganskikh' 1.5.

82 Blaramberg, Vospominaniya, p. 131; he notes that Vitkevich had become indistinguishable from his Afghan companions.

${ }^{83}$ N.A. Khalfin, 'Drama v nomerakh “Parizh”, Voprosy Istorii No. 10 (1966) pp. 216-20.

${ }^{84}$ L.G. Senyavin to V.A. Perovsky, 21 May 1839, Rossiskii Gosudarstvennyi Voenno-Istoricheskii Arkhiv [RGVIA], Fond 67 'Danzas, A.L.' Op.1 Delo 103 'Zapiski, sostavlennaya po rasskazam Praporshchika Vitkevicha, po povodu ego puteshestviya v Bukharu' l.1 ob. Part of this is reprinted in Ivanin/Golosov,
} 
A. Morrison 'Twin Imperial Disasters. The invasions of Khiva and Afghanistan in the Russian and British official mind, 1839 - 1842' Modern Asian Studies Vol.48 No.1 (2014) pp.253 - 300

personal letters, all written to Vitkevich while he was in Kabul. Three were from V.I. Dal' (18011872), Perovsky's secretary and later Russia's greatest lexicographer, who within a year would be accompanying the force marching on Khiva. ${ }^{85}$ Dal' had kept Vitkevich abreast of events in the steppe, taking advantage of their shared skill in Oriental languages to write most place names in the Arabic script. ${ }^{86}$

Vitkevich and Dal' had become close friends after the latter's posting to Orenburg in 1833, and Vitkevich wrote to him from the time of his departure with Hussain 'Ali to St Petersburg in August 1836 until he left Tehran for Kandahar in September 1837 on what he described as his 'labours of Hercules' (Gerkulesovskiza trudy). The letters reveal a wry sense of humour, and impatience at the length of his superiors' deliberations as he waited with Hussain 'Ali in St Petersburg in the summer of 1836. He refers to the British as 'artful' (khitrosplemmenyi), but the context was a whimsical passage in which he asked why they had not yet built a 'self-flyer' (samolet - the word that would eventually become the Russian for 'aeroplane') which would have allowed him a better view of the Caucasus. He reflected little on the political implications of his mission, writing only that he felt amply rewarded for it by the adventures he had already had and the new sights he had seen. ${ }^{87}$

The only other surviving materials from Vitkevich's Afghan mission appear to be a series of brief descriptions of the routes from Persia to Afghanistan compiled by him en route to Kabul, which were published in 1853 by Blaramberg, who claimed he had obtained them from Vitkevich's travelling companion, one 'Abduwahhab. Intriguingly, Blaramberg also referred to

'Abduwahhab's own account of the journey, written in Persian, which, if it ever comes to light, might shed more light on Vitkevich's character and activities. ${ }^{88}$ In its absence, however, we are little closer to understanding the man or why he shot himself. One explanation, which later reached the British via their letter-writer at Bokhara, was that Vitkevich felt humiliated because St Petersburg had repudiated the offers of support he had made to Dost Muhammad Khan. ${ }^{89}$

'Pokhod v Khivu', VS No. 1 (1863) pp. 68-70, and in a partial and inaccurate English translation in Anon, A Narrative, p. 77.

${ }^{85}$ V.I. Dal' 'Pis'ma k druzyam iz Khivinskoi Ekspeditsii', RA, Nos. 3 and 4 (1867) pp. 402-31, 606-39; Dal' was the compiler of the standard Russian dictionary: Tol'kovyi Slovar' Velikorusskogo Yazylka (St Petersburg: Tip. M. O. Vol'fa, 1881) 4 vols, and the author of numerous articles about Orenburg and the Steppe; see A.G. Prokof ev et al. (ed.) Dal', Vladimir Ivanovich. Orenburgskii krai v ocherkakh i nauchnykh trudakh pisatelya (Orenburg: Orenburgskoe knizhnoe izd., 2002) for a selection. He had earlier taken dictation of Vitkevich's report on Bukhara, and was supposed to do the same for his Afghan journey.

${ }^{86}$ Dal' to Vitkevich, Ural'sk, 3 August 1837; Dal' to Vitkevich, Orenburg, 27 September 1837; Dal' to Vitkevich, Orenburg, 2 September 1837 (all received in Kabul on 19 April 1838), AVPRI, F.161 I-5 Op.5 D.2 11.98-9, 103-4, 108-9.

${ }^{87}$ Vitkevich to Dal', 2 August 1837, 31 August 1837, 29 September 1837, 'Ya udovletvoriu sovershenno moiu strast' k prikliucheniyam... Pis'ma I.V. Vitkevicha k. V.I. Daliu', Gostinyi Dvor No. 16 (2005) pp. 304 11.

88 'Svedeniya o Persii i Afganistane, sobrannye Poruchikom Vitkevichem v 1837, 1838 i 1839 godakh', Appendix to I.F. Blaramberg (ed.) 'Statisticheskoe Obozrenie Persii sostavlennoe Podpolkovnikom I.F. Blarambergom v 1841 godu', Zapiski Imperatorskago Russkago Geograficheskago Obshchestva Knizhka VII (1853) p. 335. In his memoirs Blaramberg also notes that Vitkevich narrated many details of his Afghan travels to him, some of which he also incorporated into this text: Vospominaniya, p. 156.

89 'Translation [by Alexander Burnes] of a letter from Nazir Khan Oollah, at Bokhara to the address of the British Envoy and Minister at Cabool dated 15 ${ }^{\text {th }}$ Rajab 24 ${ }^{\text {th }}$ Sept. 1839', NAI/Foreign/S.C./18 December 1839/No. 6 Russian Agent reported to have arrived at Bokhara, p. 3. 
18 A. Morrison 'Twin Imperial Disasters. The invasions of Khiva and Afghanistan in the Russian and British official mind, 1839 - 1842' Modern Asian Studies Vol.48 No.1 (2014) pp.253 - 300

Although this and similar rumours from British sources have been uncritically repeated since as evidence of a 'disavowal' of Vitkevich's mission that led to his suicide, ${ }^{90}$ this is unlikely, partly because he had only just returned to Russia and had not even submitted a full report, but primarily because there is every indication that the authorities in St Petersburg were extremely pleased with the outcome of his mission. Vitkevich had returned to Tehran in March 1839, where Muhammad Shah Qajar awarded him the order of the Lion and the Sun, with St Petersburg's approval. ${ }^{91} \mathrm{He}$ reached St Petersburg in May, where he was given a preliminary, congratulatory debriefing by Senyavin, who pronounced himself baffled by his subsequent suicide, writing to Perovsky that in the eight days since his arrival in St Petersburg Vitkevich had seemed in excellent spirits, and that he was about to be transferred to the Guards, together with other signs of imperial approval:

On the eve of his suicide they say that they saw him again in the middle of the day, and again he was merry; in the evening he said farewell to Simonich and returned from there, and, locking himself in his room as usual, asked to be roused the next day at 9, and then shot himself. [...] All this demonstrates that the Polish jig in him overflowed [sic]. It is strange that it did not occur to him to go to Orenburg, or even on the scientific expedition [a reference to the Khiva expedition], given that he himself said many times, that he was accustomed to a vagabond life and couldn't stay in one place. ${ }^{92}$

Vitkevich's suicide note gave no clues (assuming its reliability). He made no mention of his mother, brother or friends, and simply stated that he was taking his life of his own accord and gave details of various debts that were to be settled. ${ }^{93}$ It is always possible that, as Sir John Kaye later alleged, he was murdered or driven to suicide, and that Senyavin, in this letter to his principal patron, was somehow seeking to disguise this, but this seems implausible and melodramatic, reflecting little more than British prejudices about the nature of the Russian state. ${ }^{94}$ Rather than looking to the outcome of his Afghan mission, as Senyavin's rather chilling reference to the 'Polish jig' (Pol'skaya zhiga v nem razlilos') suggests, we should instead seek the reason in his experiences as an exile. At least one of Vitkevich's fellow exiles became so depressed that he shot himself, and Peslyak wrote that he also came very close to it. Blaramberg writes that, in contrast to the playful letters he wrote to Dal' at this time, Vitkevich appeared permanently melancholy when they were travelling together from Tiflis to Tabriz, saying that he was fed up with life, and brandishing a pistol before him with the words: 'Avec ce pistolet la, je me brulerai un jour la cervelle. ${ }^{95}$ The reason for his suicide probably lies in the trauma of youthful exile and separation from his family, and perhaps a sudden surge of self-loathing and disgust at having served so well the state that had inflicted this on him. ${ }^{96}$ Suicide in early nineteenth-century Russia was often an overtly political act, an ultimate assertion of the autonomy of the individual in the face of

\footnotetext{
${ }^{90}$ Hopkins, Modern Afghanistan, p. 65.

${ }^{91}$ The original farman of investiture is on his file: AVPRI, F.161 I-5 Op.5 D.2 11.123-5.

92 Senyavin to Perovsky, 21 May 1839, RGVIA, F.67 Op.1 D.103 1.1-1ob.

93 'Tri chasa utra podlinnuyu podpisal Vitkevich', 8 May 1839 (Copy of a copy), RGVIA, F. 67 Op.1 D.103 1.4 .

${ }^{94}$ J.W. Kaye, History of the War in Afghanistan (London: W. H. Allen, 1874; third edition) Vol. I, p. 209.

${ }_{95}$ 'With that pistol, one day I shall blow my brains out.' He also blamed Vitkevich's 'sickly self-esteem' (izza boleznennogo samoliubiya): see Blaramberg, Vospominaniya, pp. 163, 222.

${ }_{96}$ Peslyak, 'Zapiski', p. 581. Dalrymple, Return of a King, pp. 200-03, also suggests this as the most likely explanation, adducing further a melodramatic account of a confrontation between Vitkevich and a childhood friend from Poland.
} 
autocratic power, and this is another possible reading of Vitkevich's death, although not necessarily the one he intended. ${ }^{97}$ What is more certain is that Vitkevich's melancholy fate contributed to the aura of mystery that he had acquired among the British, and lent credence to rumours of the sinister nature of Russian intrigue in Afghanistan.98

The official nature of Vitkevich's mission is not in doubt, but it is less clear what he had been authorized to offer- his written instructions were vague and the letter he carried contained little more than expressions of friendship and hopes for the establishment of trade relations, but while in Kabul he seems to have offered more, including financial assistance in the struggle against the British and the Sikhs. ${ }^{99}$ To the extent that he was 'Perovsky's man', he probably had the governor of Orenburg's authority to offer a degree of Russian financial support, and Volodarsky argues convincingly that, in this, Perovsky and the tsar had overridden objections from the more cautious Nesselrode. ${ }^{100}$ Vitkevich's presence was certainly designed to strengthen Dost Muhammad's resolve to resist British blandishments, creating in Afghanistan a barrier to the further encroachment (as the Russians saw it) of British trade and political interests into Central Asia. Almost a mirror image, in other words, of what the British were simultaneously trying to achieve in Afghanistan, but not a direct attempt to threaten British security in India. The British response-an outright invasion and occupation of Afghanistan-was disproportionate to the threat posed by Vitkevich and his mission. The Persian attack on Herat was a more concrete threat to India's security, but even as preparations for the deposition of Dost Muhammad were being put in place, Auckland received news that the siege had failed, partly owing to the efforts of a British officer, Eldred Pottinger, in strengthening Herat's defences. Nevertheless, Auckland insisted that the operation must go ahead 'to raise up a permanent barrier against schemes of aggression from that quarter'. ${ }^{101}$ The fear of an extension of Russian influence into Central Asia continued to drive British policy.

It was Burnes who, partly as a means of exaggerating the importance of his mission, talked up the Russian threat ('a cabinet, Oriental and dark in its diplomacy'102), and who gradually, with McNeill in Tehran, and the foreign member of the Governor-General's Council, William Hay Macnaghten (1793-1841), won over the more cautious Auckland to the necessity of pursuing an aggressive policy in Afghanistan. Burnes would reiterate this position in his last despatch from Afghanistan, sent from Jalalabad on the road back to Punjab, stating that 'consequences of a most serious nature' would flow from the situation in Central Asia unless the British government

\footnotetext{
${ }^{97}$ Susan Morrissey, 'In the Name of Freedom: Suicide, Serfdom and Autocracy in Russia', Slavonic and East European Review Vol. 82 No. 2 (April 2004) pp. 271-78, 290-91.

${ }^{9}$ This was partly because they had so little accurate information about him. See, for instance, Stoddart to Burnes, 9 February 1838, PP Vol. XXV.7 No. 1 (8 June 1859) p. 169, where he refuses to believe that Vitkevich could be a Pole, because he was in a Cossack regiment.

${ }^{99}$ Yapp, Strategies, pp. 234-35; Mosely, 'Russian Policy in Asia', p. 671. Blaramberg's later assertion that Vitkevich's mission was not 'political' was almost certainly disingenuous: Vospominaniya, pp. 129-30.

${ }^{100}$ Volodarsky, 'The Russians in Afghanistan', p. 73.

101 Auckland to the Secret Committee, 13 March 1839, 'East India (Cabul and Affghanistan). Correspondence of the Governor General of India with the President of the Board of Control and with the Secret Committee of the East India Company [...] relative to the expedition to Affghanistan, or such part thereof as has not already been published' PP Vol. XXV.7 No. 1 (8 June 1859) p. 303; Hopkins is thus wrong to suggest that 'the Russians' (sic) were still besieging Herat once Shah Shuja had been installed: Afghanistan, p. 66.

102 Burnes to Auckland, 23 December 1837, PP Vol. XXV.7 No. 1 (8 June 1859) p. 92; this phrase, so redolent of British prejudices about Russia, was not published in the original, 'garbled' papers of 1839.
} 
20 A. Morrison 'Twin Imperial Disasters. The invasions of Khiva and Afghanistan in the Russian and British official mind, 1839 - 1842' Modern Asian Studies Vol.48 No.1 (2014) pp.253 - 300

'applies a prompt, active and decided counteraction' to the machinations of Russia, 'a nation which makes no scruple to dazzle men's minds by promises'.103 Burnes's solution to this problem, as is well known, was the creation of a strong, unified Afghan state able to resist Persian and Russian aggression, and he exceeded his instructions by promising British arms and money to Dost Muhammad Khan's brothers at Kandahar to resist the Persians. For this he was rebuked by Auckland, who feared that the creation of a more powerful Afghan state on British India's frontiers might become a threat in itself, and would certainly be viewed unfavourably by Britain's oldest and most important ally in the region, Ranjit Singh. At this stage Auckland professed to attach 'little importance' to the arrival of a Russian agent in Kabul, but later revised this opinion. ${ }^{104}$ Auckland would eventually write to the Court of Directors that, although he had no objection in principle to the tsar's original letter to Dost Muhammad, he viewed Simonich's role with much greater suspicion. ${ }^{105}$

A month later Burnes wrote: 'I am at Simla with the Governor General, who has determined to place Shah Shooja on the throne in the cold weather' and suggested that Vitkevich's presence at Kabul had proved crucial in reaching this decision. ${ }^{106}$ Yapp has shown how rapidly—and with how little consideration — what was originally supposed to be an arm's-length mission mounted by the Sikhs in support of Shuja's restoration evolved into the re-creation of Afghanistan as a fully fledged buffer state under British control, the cornerstone of a new system of imperial defence. Auckland would later claim that Dost Muhammad had already made up his mind to ally himself with the Russians and Persians as early as November 1837, but there is no evidence for this-and Burnes's negotiations suggest the contrary. It was an expost facto justification for the aggressive policy Auckland had decided to embark upon early in 1838. Auckland believed that Shuja's 'legitimacy' as the representative of the senior branch of the Durrani dynasty would lead the Afghans to welcome his return and the ousting of the 'usurper', Dost Muhammad. Subsequent events would show that Auckland had overestimated Shah Shuja's popularity in Afghanistan, something that became obvious within weeks of the Sadozai ruler's restoration. Nevertheless the conviction persisted that the blood descent of a ruler counted for more with 'Asiatics' than his popularity or competence, and that the hierarchical nature of Afghan society meant that simply replacing one ruler with another would be sufficient to establish British control.

Thus crucial decisions over Afghan policy were taken on the basis of faulty intelligence and an exaggerated fear of Russia by a small group of officials in India, albeit within parameters set by London where, at that particular juncture, Palmerston was quite happy to see Russia thus baulked. ${ }^{107}$ By the middle of 1839 the British also had another justification for advancing beyond the Indus-long-standing rumours that the Russians were planning an invasion of Khiva had been confirmed. This caused concern, not because the British thought it a prelude to an invasion of India or Afghanistan, but because it would create unrest and rumour in India itself, and make

\footnotetext{
${ }^{103}$ Burnes to Macnaghten, 30 April 1838, PP Vol. XXV.7 No. 1(8 June 1859) p. 229. Here too the final phrase was not published in 1839.

104 Macnaghten to Burnes, 20 January 1838, PP Vol. XXV.7 No. 1 (8th June 1859) pp. 111-15. See Norris, First Afghan War, pp. 120-54, for a detailed account of how Burnes misinterpreted and exceeded his instructions.

105 Auckland to the Secret Committee, 8 February 1838, PP Vol. XXV.7 No. 1 (8 June 1859) p. 279.

106 Burnes to Jacob, 8 August 1838, NAI/Foreign/S.C./28 September 1842/Nos.33-42 pp. 11-12.

107 Yapp, Strategies, pp. 240-52, 270-303.
} 
A. Morrison 'Twin Imperial Disasters. The invasions of Khiva and Afghanistan in the Russian and British official mind, 1839 - 1842' Modern Asian Studies Vol.48 No.1 (2014) pp.253 - 300

the Russian alternative to British patronage in Central Asia seem all the more attractive. As Auckland wrote a year later, by which time (although the British did not yet know this) the last remnants of Perovsky's frostbitten and scurvy-ridden troops were staggering back into Orenburg:

I have no great fear that the Cossack and the Sepoy will shortly meet on the Oxus, nor do I apprehend that overwhelming armies will be poured down the Volga from Russia into Turkistan [...] but I look to effects from the occupation of Khiva by the Russians, in the maintenance of irritation and division, and in the notion which will be created that there are two standards, under either of which the turbulent of all these States may range themselves. ${ }^{108}$

\section{The genesis of the Khiva expedition}

If the British invasion of Afghanistan - which was widely reviled even at the time as an unprovoked attack on a neighbouring ruler-seemed to come out of the blue, the Russian invasion of Khiva was generally seen as justified by substantial grievances. The Russians could point to Khivan raids on caravan traffic and repeated attempts to extract revenue from nomadic groups over whom the Russians claimed sovereignty. The more historically minded could also invoke the massacre of Prince Bekovitch-Cherkassky's expedition in 1717, or the supposed 'political testament' of Peter the Great, which called for the subjugation of Khiva. ${ }^{109}$ Above all, as Madhavan Palat has suggested, the presence of what were variously estimated as hundreds or thousands of Russian slaves in the Khanate, captured by Kazakh or Turkmen raiders along the Orenburg line and the Caspian coast, played a crucial role in legitimating and motivating the Russian advance. This was despite the fact that the number of Russian slaves was grossly exaggerated (in fact, most of the Khanate's slaves were Shia Persians), that Russia itself was engaged in slave trafficking in the Caucasus in the same period, and that many of the 'slaves' were in fact prisoners of war. ${ }^{110}$ The effectiveness of these complaints in a diplomatic sphere dominated by the rhetoric of anti-slavery can be seen in the government of India's acknowledgment that it was a legitimate justification for a punitive expedition, even though it feared that a permanent Russian presence in Khiva might be damaging to Indian security. ${ }^{111}$ What gave these reasons for attacking Khiva force and urgency within Russia was the new, selfconscious sense among the administrative and military elite that they were the servants of a European 'Great Power' with prestige and standards to maintain, a tendency Michael Khodarkovsky identified on the steppe frontier as early as the 1750s (where it took the form of a mission civilizatrice), and which reached its apotheosis in 1814, when Alexander I marched into Paris. ${ }^{112}$

108 Minute by the Governor-General, 7 June 1840, India Office Records, British Library [IOR]/L/PS/20/G10/3 Letters from the Governor-General of India in Council to the Secret Committee No. 8 p. 12.

${ }^{109}$ René Letolle, 'Les Expeditions de Bekovitch—Tcherkassky (1714-1717) en Turkestan, et le debut de l'infiltration Russe en Asie Centrale', Cabiers d'Asie Centrale No. 5 (1998), pp. 259-85.

110 Madhavan K. Palat, 'Tsarist Russian Imperialism', Studies in History Vol. 4 Nos. 1 \& 2 (1988) pp. 163-66.

111 Torrens to Macnaghten, 25 May 1840, IOR/L/PS/G10/3 No. 6 p. 8; see Richard Huzzey, Freedom Burning. Anti-Slavery and Empire in Victorian Britain (Ithaca, New York: Cornell UP, 2012) pp.51-65, 206-10. 112 Michael Khodarkovsky, Russia's Steppe Frontier. The Making of a Colonial Empire 1500-1800 (Bloomington, Indiana: Indiana UP, 2002) pp. 225-26. On the profound impact that victory in the Napoleonic Wars had on the ideologies and self-perception of the empire's governing elite, see D.C.B. Lieven, 'Russia and the Defeat of Napoleon (1812-14)', Kritika: Explorations in Russian and Eurasian History Vol. 7 No. 2 (Spring 2006) pp. 283-308. 
22 A. Morrison 'Twin Imperial Disasters. The invasions of Khiva and Afghanistan in the Russian and British official mind, 1839 - 1842' Modern Asian Studies Vol.48 No.1 (2014) pp.253 - 300

The attack on Khiva had a lengthy genesis: in 1804 Prince G.S. Volkonsky, the governor of Orenburg, proposed a punitive expedition to Alexander I, although at that time there were other pressing foreign policy priorities. In 1819 Captain N.N. Murav'ev was despatched on a mission to Khiva from Tiflis, and succeeded not only in traversing the Turkmen country to reach the Khivan oasis, but also, more remarkably, in returning alive, but without procuring any lasting agreement or securing the release of any slaves. ${ }^{113}$ In 1831 the head of the Orenburg Frontier Commission, General G.F. Gens, wrote a strongly worded memorandum on the plight of the Russian prisoners in Khiva, which in 1833 prompted Nesselrode to acknowledge that an expedition ought to be sent to free them, although he was concerned about the cost and the difficulties of the route. ${ }^{114}$ Thus there was agreement in principle to some sort of punitive expedition even before Perovsky's arrival in Orenburg, although its feasibility had yet to be established. As Zakhar'in recounted it, on taking up his post in 1833 on the death of Governor Sukhtelen, Perovsky was shocked to discover that Kazakhs around the Ural River, while nominally acknowledging Russian sovereignty, were still in the habit of capturing Russian subjects and selling them into slavery in Khiva. One particularly affecting tale concerned a Cossack officer's widow who was kidnapped from Orenburg itself in 1825, on the eve of the first visit to the town by Alexander I. Thanks to the latter's intervention she was eventually found and brought back, but even the autocrat of all the Russias had been forced to offer a large sum to her captors. ${ }^{115}$ Whether this story is true or not, Perovsky clearly felt a strong, almost personal, sense of affront and moral outrage at Khiva's enslavement of Russians. In 1834 he asked the Orenburg Frontier Commission to prepare a list of known Russian prisoners held in Khiva, which eventually amounted to 599 names. ${ }^{116}$ Early the following year he sent a melodramatic memorandum to St Petersburg, advocating a punitive expedition and invoking the common 'civilizing' mission of the European powers in the Muslim world:

The guilt of the Dey of Algiers against the King of the French pales into insignificance in comparison with the crimes carried out by whole generations of Khivan Khans against the Emperors of Russia [...] there a single, momentary, and in reality bloodless insult to the Consul; here in the course of a whole century constantly accumulating perfidy which increases day by day, deliberate malice, robbery, banditry and disrespectful abuse of Majesty; here the blood of Russians is spilled, has been flowing for a whole century [...] thousands have suffered and suffer now under the yoke of slavery [...] France demanded millions for the conquest of Algeria, and has retained for all time her conquests beyond the restitution of what she has spent. For Russia

113 N.N. Murav’ev, Puteshestvie v Turkmeniyu i Khivu v 1819 i 1820 godakh (Moscow: Tip. Augusta Semena,1822).

${ }^{114}$ S.N. Sevast'yanov, 'Sobytiya v Orenburgskom krae podgotovivshiya ekspeditsiyu v Khivu 1839_ 1840gg.', Trudy Orenburgskoi Uchenoi Arkhivnoi Komissii Vyp. XVI (1906) pp. 108-14, 125-26, 131-32, 14042.

115 Zakhar'in, Khiva, pp. 20-22.

116 Twenty of these were women, and 57 had Muslim names. Perovsky to the Orenburg Frontier Commission [O.P.K.] 30 April 1834; O.P.K. to Perovsky, 2 June 1834, Tsentral'nyi Gosudarstvennyi Arkhiv Respubliki Kazakhstan [TsGARKaz] F.4 ‘Oblastnoe Pravlenie Orenburgskimi Kirgizami’ Op.1 D.1567 'Spisok Russikh plennykh nakhoodyashchikhsya v sredneaziatskikh khanstvakh' 11.1, 3-25ob. 
A. Morrison 'Twin Imperial Disasters. The invasions of Khiva and Afghanistan in the Russian and British official mind, 1839 - 1842' Modern Asian Studies Vol.48 No.1 (2014) pp.253 - 300

the conquest of Khiva would not cost one tenth of this; but all of Central Asia would be revived, would rise up from its torpor with the introduction of an educated, beneficial government. ${ }^{117}$

The sense of competitive imperial emulation emerges clearly: Russia could not be left behind by Britain and France, nor could one of Europe's Great Powers continue to tolerate the insults of a petty Asiatic state like Khiva. The response from the war minister, A.I. Chernyshev (1786-1857), was enthusiastic: he wrote that the tsar was entirely in agreement with the memorandum's sentiments and wished to see a detailed plan for an expedition; once again, Perovsky's close personal connection with Nicholas I had borne fruit. ${ }^{118}$ The first practical consequence of this was an imperial decree of 1836 ordering the detention of over 350 Khivan merchants in the menovoi dvor (Asian caravanserai) outside Orenburg and a total suspension of Russian trade with the Khanate. ${ }^{119}$ Military preparations were temporarily postponed owing to a rebellion among the Kazakhs, and to what the Khan of Khiva would later describe to James Abbott as genuine efforts to reach a diplomatic settlement by freeing some of the Russian slaves. ${ }^{120}$ Ivanin wrote that the Russians simply saw these as delaying tactics, possibly inspired by British interference. ${ }^{121}$ Perovsky himself, while paying lip-service to the idea that the trade embargo might be used to bring Khiva to the negotiating table, made it clear that nothing less than the immediate release of what he claimed were 3,000 Russian prisoners in the Khanate would do: 'the Khivans meet their guests with knives, poison or the shackles of a prisoner'. ${ }^{122}$ In practice he was not prepared to negotiate: when two Khivan envoys arrived with five freed Russian prisoners in August 1838 Perovsky refused to receive them, had them detained with the merchants, and interrogated the ex-slaves for useful information. ${ }^{123}$ In March 1839 the special committee, consisting of Perovsky himself, Nesselrode and Chernyshev, which met to consider Perovsky's proposal for a military expedition added a further consideration:

... beyond its stated principal aim, it must have another, still more important: to establish and consolidate the influence of Russia in Central Asia, weaken the long-standing impunity of the Khivans, and especially that constancy with which the English government, to the detriment of our industry and trade, strives to spread its supremacy in those parts. [...] however, bringing into consideration the current state of affairs in Central Asia, we consider it more convenient to

\footnotetext{
117 'Zapiska o snosheniyakh Rossii s Khivinskim khanstvom i o protivnykh narodnym pravam postupkakh khanov Khivinskikh protiv Rossii', Perovsky to Chernyshev, January 1835, Serebrennikov Sbornik. Vol. I Doc. 6 p. 28

${ }_{118}$ Chernyshev to Perovsky, 14 January 1835, Serebrennikov Sbornik Vol. I Doc. 6 pp. 28-29.

119 Perovsky to the Orenburg Frontier Customs, 14 August 1836, Gosudarstvennyi Arkhiv Orenburgskoi Oblasti [GAOrO] F.153 'Orenburgskaya Pogranichnaya Tamozhnya' Op.1 D.153 'Perepiska s Orenburgskim Voennym Gubernatorom i Orenburgskim tamozhnym okrugom o zaderzhanii khivintsev’ 11.1, 5-12ob. Vitkevich referred to these arrangements approvingly in a letter to Dal', 6 September 1837: 'Ya udovletvoriu' p. 305.

120 Abbott, Narrative, Vol. I, pp. 108-10.

${ }^{121}$ Ivanin/Golosov, 'Pokhod v Khivu', VS No. 1 (1863) pp. 70-71; Anon, A Narrative, pp. 52-69.

122 Perovsky Memorandum, 18 September 1836, GAOrO F.167 'Chernov, I. V.' Op.1 D.27 ‘O vzaimotnosheniyakh Khivy i Bukhary s Rossiei' ll.1-4.

${ }_{123}$ Gub. Sek. Aitov to the O.P.K., 10 August 1838; Zhurnal O.P.K., 15 August 1838, TsGARKaz F.4 Op.1 D.333 'O pribyvshikh iz Khivy dvukh poslantsev' 11.14, 35-46, 52-ob.
} 
24 A. Morrison 'Twin Imperial Disasters. The invasions of Khiva and Afghanistan in the Russian and British official mind, 1839 - 1842' Modern Asian Studies Vol.48 No.1 (2014) pp.253 - 300

postpone the mission to Khiva until the end of the expedition undertaken by the GovernorGeneral of the British possessions in India against the ruler of Kabul, Dost Muhammad. ${ }^{124}$

In other words, while the Khiva expedition would hopefully combat British influence by reviving both Russia's trade and her prestige in Central Asia, they were anxious to avoid an open clash. The committee added that alluding to the Afghan example would be a sufficient response to any British complaints, but it would be better to wait until the outcome there had been decided. In April 1840, Nesselrode wrote to Perovsky to let him know the substance of what had passed between the Russian Foreign Ministry and the British government, which evidently regarded the Khivan expedition with suspicion, seeing it as a response to their invasion of Afghanistan and an attempt to meddle with its affairs. Nesselrode claimed to have dispelled these fears by explaining Russia's grievances against Khiva and categorically denying that the expedition had anything to do with the invasion of Afghanistan. ${ }^{125}$

Nevertheless, the committee also cited Afghanistan when it came to the expedition's aims, one of which would be to depose the khan of Khiva, Allah Quli, and replace him with a Russian client: 'this measure, which is not against the customs of the asiatics, would be entirely consistent with the actions of the British in their current expedition against Dost Muhammad Khan, the declared purpose of which [...] lies in the deposition of its ruler and the restoration of its former Shah, Shuja ul-Mulk'. ${ }^{126}$ However the proposed candidate, Sultan Bai Muhammad Aichuvakov, head of the western section of the Orenburg Kazakhs, wisely turned down the opportunity to become the Russian Shah Shuja (although he would later accompany the expedition). Instead Perovsky proposed replacing Allah Quli with his younger brother, Rahman Quli Inaq, who was rumoured to be 'a very reasonable man, and, so far as is known, secretly wishes the friendship and patronage of Russia'. ${ }^{127}$ There was no indication of where this information had come from, or indeed of whether the Khan's brother had been made aware of the honour in store for him. The Russians did not even know his name, referring to him simply as 'Inaq', which was not a name but a title conventionally bestowed on the younger brother of the khan. ${ }^{128}$ Richmond Shakespear, who met Rahman Quli at Hazarasp in 1840, certainly had no inkling that he was under consideration as a potential Russian ally. ${ }^{129}$ Despite this, Nesselrode endorsed the proposal, reiterating that by preserving the same dynasty in power it would be agreeable to the understanding of 'Asiatics', and again pointed to parallels with British policy in Kabul. ${ }^{130}$ Any further details seem to have become swamped in the sheer logistical complexity of sending a military force into the barren steppe in winter, and the plans for Khiva's future government in the event of the expedition's success remained vague until its departure. One of the few

124 'Zhurnal Komiteta, razsmotrivavshago predpolozheniya Orenburgskogo voennogo gubernatora o poiske na Khivu', 11 March 1839, Serebrennikov Sbornik Vol. I Doc. 12 p. 33.

${ }^{125}$ Nesselrode to Perovsky, 5 April 1840, Serebrennikov Sbornik Vol. II Doc. 64 pp. 104-06.

126 'Zhurnal Komiteta, razsmotrivavshago predpolozheniya Orenburgskogo voennogo gubernatora o poiske na Khivu', 11 March 1839, Serebrennikov Sbornik Vol. I Doc. 12 p. 35.

127 Perovsky to Nesselrode, 30 September 1839, Serebrennikov Sbornik Vol. I Doc. 93 pp. 148-50.

128 T.K. Beisembiev, Annotated Indices to the Kokand Chronicles (Tokyo: ILCAAS, 2008) p. 727. The Uzbek Qungrat dynasty of Khiva had been established by Muhammad Amin Inaq in 1770-71 when he recaptured the khanate from the Yomut Turkmen, although the fiction of Chingissid rule would be preserved until 1804: see Yuri Bregel (ed. and trans) Firdaws al-Iqbal. History of Khorezm (Leiden: Brill, 1999) pp. 95-122. ${ }^{129}$ Shakespear, 'Narrative', p. 702.

130 'Zhurnal komiteta, razsmatrivavshavo predpolozhenie Orenburgskogo voen. Gubernatora o poiske v Khivu', 10 October 1839, Serebrennikov Sbornik Vol. I Doc. 101 pp. 158-63. 
A. Morrison 'Twin Imperial Disasters. The invasions of Khiva and Afghanistan in the Russian and British official mind, 1839 - 1842' Modern Asian Studies Vol.48 No.1 (2014) pp.253 - 300

indications that any thought had been given to this was a small (and as it turned out, very premature) pamphlet published in 1840 which contained wildly inaccurate claims about the wealth and resources of Khiva which would accrue to Russia after its conquest. ${ }^{131}$

Because the Khivan expedition was halted by the weather, Perovsky was later able to claim that it remained militarily undefeated. The political and military planning and intelligence behind the expedition received far less scrutiny than that of the British in Afghanistan, where European troops had been very publicly worsted by supposedly 'savage' tribesmen. Instead the Russians emphasized the one engagement they had with the enemy, when a small detachment under Captain Erofeev easily defeated a group of Khivan raiders: in his address to the troops on announcing the decision to retreat, Perovsky made great play of the 'contemptible' and 'cowardly' nature of the enemy with which the Russians had failed to come to grips. ${ }^{132}$ Although the Russian force was indeed almost certainly superior to anything Allah Quli could have put in the field, it was still small and it seems likely that even if the weather had been more favourable, it would have been exhausted and in severe need of supplies by the time it reached the cultivated lands of the Khanate.

If James Abbott's account is to be believed, Allah Quli Khan was well aware of the size of the advancing force (4,000 to 5,000 men) and of the fact that by January 1840 they were stuck fast in the snow. ${ }^{133}$ Even if other rumours had not reached him before, the khan would have been alerted to the preparation of the expeditionary force when the lengthy and complicated process of assembling the 10,000 camels required for transport began in August 1838. ${ }^{134}$ At this stage the cover for the preparations remained a 'scientific expedition', but given the prodigious numbers involved, this soon wore rather thin: Ivanin described how already in March 1839 the female traders of the Orenburg bazaar knew that an expedition against Khiva was being prepared, while 'false' rumours about Russian movements were circulating in the Steppe. ${ }^{135}$

By May 1839 the Kazakhs clearly knew that a military expedition was being prepared, as the Biis (judges) of the Nazarov division wrote to General Gens expressing their relief on learning that it was not intended to chastise them: 'it is not unknown to your Excellency that our people were afraid of the force which you are sending out, not knowing the reason'-Gens, however, refused the request to be told the route the expedition would take. ${ }^{136}$ Rumours of these preparations spread far ahead, as Alexander Burnes had already heard of them in garbled form from his agent in Bukhara in October 1839.137 Allah Quli thus had ample warning of the Russian advance and

${ }^{131}$ Ivan Koritskii Khiva, ili geograficheskoe i statisticheskoe opisanie Khivinskago Khanstva, sostoyashchago teper' v voine s Rossiei (Moscow: Universitetskaya Tip., 1840)

132 'Prikaz po otryadu voisk Khivinskoi ekspeditsii', 1 February 1840, Serebrennikov Sbornik Vol. II Doc. 22 p. 42; an English translation of this document can be found in Anon, Narrative, pp. 165-66.

133 Abbott, Narrative, p. 110.

${ }_{134}$ Gens to Sultan Bai Muhammad Aichuvakov, 27 August 1838; Sultan Bai Muhammad Aichuvakov to Gens, 12 September 1838, TsGARKaz F.4 Op.1 D.2167 'Materialy ob otpravke v Khivu voennogo otryada dlya osvobozhdeniya russkikh plennykh' $11.1,3 o b-4 o b$.

${ }_{135}$ M. Ivanin, 'Zametki po povodu napechatannoi vo 2 i 3 numerakh "Voennago Sbornika" nyneshnago goda stat'i “pokhod v Khivu 1839g."” VS No. 4 (1863) p. 490; Ivanin/Golosov, 'Pokhod v Khivu', VS No. 2 (1863) p. 352; Anon, Narrative, p. 119.

136 Biis of the Nazarov division to Gens, 25 May 1839; Gens to the Biis of the Nazarov division, 26 May 1839 TsGARKaz F.4 Op.1 D.2167 1l.33ob-36.

137 'Translation [by Alexander Burnes] of a letter from Nazir Khan Oollah, at Bokhara to the address of the British Envoy and Minister at Cabool dated 15 th Rajab 24th Sept. 1839', NAI/Foreign/S.C./18 December 
26 A. Morrison 'Twin Imperial Disasters. The invasions of Khiva and Afghanistan in the Russian and British official mind, 1839 - 1842' Modern Asian Studies Vol.48 No.1 (2014) pp.253 - 300

had made preparations to resist it. ${ }^{138}$ After the expedition's failure, the commander of the NovoAlexandrovsk fortress sent in a proclamation in 'Tatar' that a spy had brought him, which bore the khan of Khiva's seal, and which urged Kazakh and Turkmen Biis and Batyrs (heroes) to join him in fighting against the Russians. ${ }^{139}$

Perovsky's scheme to depose a khan who seems to have been a fairly popular ruler was based, as in the case of Auckland's removal of Dost Muhammad, on a mixture of prejudice and poor (or non-existent) intelligence. If at first sight the Russians appeared to have a stronger case for invading Khiva than the British had had in Afghanistan, their specific grievances against Allah Quli Khan were only part of the story. Like the British, they saw their invasion as a means of countering a threat from another great power in Asia and, like the British, they had devised an illthought-out scheme to impose a ruler of their choice on a neighbouring state, in the expectation that, as 'Asiatics', the population would simply submit. Both powers also indulged in dubious legal justifications for their acts of aggression - the British by claiming that Dost Muhammad was a usurper, while Ivanin later asserted that in the eighteenth century the Khivans had chosen five Khans in succession who were 'Russian subjects' by virtue of being 'Kirgiz' (Kazakh), and that therefore Russia had an 'indisputable claim' to sovereignty over Khiva. ${ }^{140}$ However, the political failings of the Russian plans for Khiva were never revealed as starkly as those of the British occupation of Afghanistan, because the Russian forces never reached their destination.

\section{Ignoring the 'native' voice}

We should perhaps be wary of using hindsight to criticize the follies of 1839, although Perovsky and Auckland were not exactly the sort of people that E.P. Thompson had in mind when he referred to the historian's task as rescuing his subjects 'from the enormous condescension of posterity'. ${ }^{141}$ From our current standpoint, British and Russian imperialist adventures in Central Asia seem morally repugnant in and of themselves, but it is still important to understand why they were unable to translate their substantial military superiority into victory and territorial annexation_-or even a stable diplomatic relationship with the Central Asian states. In the aftermath of the Afghanistan disaster, people flocked to denounce Auckland's policy, but fewer condemnatory voices were heard beforehand. The failure of the Khiva expedition, meanwhile, could be attributed to an Act of God over which nobody had any control. However, in both cases there were contemporary voices that pointed out the errors in British and Russian policy, and it is important to establish why they were not listened to. For Afghanistan, the most celebrated is that of Sir Alexander Burnes — 'the martyr of Kabul' — canonized after his death by Sir John Kaye and by his surviving relatives. ${ }^{142}$ Although Burnes had initially wanted the British to support Dost Muhammad, once that had been ruled out by Auckland, he agreed to support the alternative policy of restoring Shah Shuja-his private correspondence makes it quite clear that

1839/No. 6 Russian Agent reported to have arrived at Bokhara, p. 3. Yapp was puzzled as to how rumours of Russian troop movements could have reached the British at Kabul months before the Khivan expedition actually set out in November 1839 (see Strategies, pp. 391-92), but given how far ahead the preparations were initiated, the explanation is quite simple.

138 Abbott, Narrative, Vol. I, p. 97.

${ }^{139}$ Lt. Col Likhamerstov to Perovsky, 24 May 1840, TsGARKaz F.4 Op.1 D.2182 'O vystuplenii voennykh otryadov protiv Khivy' l.15.

${ }^{140}$ Ivanin/Golosov, 'Pokhod v Khivu', VS No. 3 (1863) p. 34; Anon,Narrative, p. 39.

${ }^{141}$ E. P. Thompson, The Making of the English Working Class (London: Victor Gollancz, 1963) p. 12.

142 Alder, 'The "Garbled” Blue Books', pp. 237-39, 253. 
A. Morrison 'Twin Imperial Disasters. The invasions of Khiva and Afghanistan in the Russian and British official mind, 1839 - 1842' Modern Asian Studies Vol.48 No.1 (2014) pp.253 - 300

he considered some kind of decisive action to counter Russian intrigues to be the overriding priority, and that his own personal ambition played a substantial part in this..$^{143}$

In any case, Burnes's misgivings are so well known that he can hardly be considered a silenced voice, and on the subject of the Russian threat he was listened to - with disastrous results. Instead, even using purely British and Russian accounts, it rapidly becomes clear that the voices that were almost entirely ignored were those of the 'natives' or 'tuzemtsy'. This can be seen, first, in accounts of diplomatic relations, where neither the British nor the Russians were prepared to deal with Central Asian rulers on anything approaching equal terms,. This disregard is echoed in much 'Great Game'-dominated historiography, which views Central Asia as no more than a 'chessboard' on which the great powers made their moves and ignores the crucial role played by local states and their rulers. ${ }^{144}$

Perovsky entirely ignored the repeated attempts of Allah Quli Khan to reach a negotiated settlement of the outstanding grievances between Russia and Khiva. On the khan's side, this included the construction of the Russian fortress at Novo-Alexandrovsk on what he considered to be Khivan territory; for the Russians this matter was not even negotiable. ${ }^{145}$ The Russians responded to these overtures (which Ivanin would later describe as a typical instance of Oriental untrustworthiness) by detaining all Khivan ambassadors and merchants and refusing further dialogue. ${ }^{146}$ Meanwhile, both Burnes and Abbott had a greatly exaggerated idea of the attractiveness of a British alliance to Central Asian rulers. Allah Quli Khan had sent a straightforward response to a letter from Pottinger in Herat that had requested him to satisfy Russia's grievances by releasing the slaves at Khiva. After pointing out that Yar Muhammad Khan, who ruled Herat under British auspices, was also a keen slave trader, Allah Quli Khan wrote that he was preparing for conflict with Russia and asked the British to send him some experienced artillerymen as a mark of their good faith. ${ }^{147}$ The government of India consistently refused to offer anything other than empty assurances of friendship. As the prime minister (mehtar) of Khiva bluntly told Abbott: 'What then have you come hither for? If you will grant none of our demands, of what use is it to call yourselves our allies?' 148 Similarly, in response to Lord Auckland's grudging offer to 'restrain' Ranjit Singh in return for Dost Muhammad's allegiance, Nawab Jabbar Khan, one of the amir's brothers, who was friendlier to the British than any other Barakzai, told Burnes plainly that British promises to 'protect' Dost Muhammad against Ranjit Singh were worthless, as the Afghan ruler did not fear an attack from that quarter:

\footnotetext{
${ }_{143}$ Burnes to Jacob, 10 December 1838, NAI/Foreign/S.C./28 September 1842/Nos. 33-42 pp. $19-21$.

144 This is most obviously true of Peter Hopkirk's The Great Game. On Secret Service in High Asia (London: John Murray, 1990) but it also affects Yapp's work and, most recently, E. Yu Sergeev Bol'shaya Igra, 18561907: mify i realii rossiisko-britanskikh otnoshenii v Tsentral'noi i Vostochnoi Azii (Moscow: Tovarichestvo nauchnykh izdanii KMK, 2012). See Hopkins, Afghanistan, pp. 34-37 for an effective critique of this tendency.

${ }^{145}$ Khwarazmshah to Perovsky (Russian translation), 11/1836 GAOrO F.167 Op.1 D.35 'Pis'mo Khorezmskogo Shakha o narushenie russkimi druzhestvennykh otnoshenie s Khorezmom’ 11.1-2ob. 146 Ivanin/Golosov, 'Pokhod v Khivu', VS No. 1 (1863) pp. 70-1; Anon, A Narrative, pp. 52-69. 147 'Firman addressed by the Khan Huzrut of Khiva to the British Envoy at Herat', received 10 December 1839, IOR/L/PS/20/G10/3 No. 14 pp. 9-10.

148 Abbott, Narrative, Vol. I, p. 100.
} 
28 A. Morrison 'Twin Imperial Disasters. The invasions of Khiva and Afghanistan in the Russian and British official mind, 1839 - 1842' Modern Asian Studies Vol.48 No.1 (2014) pp.253 - 300

... it appeared that we valued our offers at a very high rate, since we expected in return that the Afghans would desist from all intercourse with Persia, Russia, Toorkistan, \& c. Were the Afghans to make all these powers hostile, and receive no protection against the enmity raised for their adhering to the British?'149

Many of the subsequent mistakes made by Auckland and his cabinet stemmed from a refusal to accept the justice of this remark, as repeated opportunities to establish good diplomatic relations with Dost Muhammad were spurned. The sad tale of the disasters that followed the decision to depose him and set up Shuja ul-Mulk is too well known to be rehearsed at length here, but an inability or refusal to understand local points of view remained a common factor. ${ }^{150}$ As Kim Wagner has shown, although 'native informants' remained important to the British in the early nineteenth century and were often invoked to add authority to intelligence reports, the raw information they provided was increasingly ignored or woven into new and fantastical forms if it did not coincide with official preconceptions. ${ }^{151}$

Beyond the frontiers of the East India Company's territory, increasingly the crucial figure was not the independent local 'newswriter', but the British agent who reinterpreted his missives to suit his own purposes and repackaged them for Calcutta, of which Burnes was the pre-eminent example. ${ }^{152}$ He certainly had a network of informants, who ensured that he knew that all was not well, as he frequently noted in his letters before the disaster. ${ }^{153}$ However, in the days leading up to his murder Burnes also ignored numerous warnings from 'native' sources. The most vehement of these came from his erstwhile companion, the Kashmiri, Mohan Lal. ${ }^{154}$ Lal survived the massacres, and would subsequently provide some clear-sighted analyses of what went wrong, but it is instructive to compare the reception of his writings on the Kabul disaster with those of British critics such as Burnes, Kaye or David Urquhart. General Pollock, forwarding Lal's report on the affairs of Afghanistan, wrote that ${ }^{\circ}$ The subject is one of two [sic] great importance to be ably treated by a person so indifferently educated as the Moonshee. ${ }^{155}$ It was clear that most of the value attached to Lal's testimony was because of his association with Burnes: he could be an informant, but not an agent in his own right. Lal was still in Kabul, living in the house of a merchant called 'Khan Sheree'. ${ }^{156} \mathrm{He}$ thus had access to better intelligence than either the garrison at Jalalabad or the British hostages seized by the Afghans (the other main sources of information at this stage). His memorandum summed up the various reasons why the rebellion in Kabul had taken place and why the garrison there had failed to quell it. He focused primarily on the inadequacy of Shah Shuja's ministers, the drunkenness of the British troops, the sexual conquests made by their officers among the Afghan women, the decision to withdraw allowances from many of the tribes in Kohistan and along the vital supply route to the Khyber (where he

\footnotetext{
${ }_{149}$ Burnes to Macnaghten, 5 March 1838, PP Vol. XXV.7 No. 1(8 June 1859) p. 162.

150 See Norris, First Afghan War, pp. 337-60, Yapp, Strategies, pp. 307-50; M.E. Yapp, 'Disturbances in Eastern Afghanistan, 1839-42', Bulletin of the School of Oriental and African Studies Vol. 25 No. 3 (1962) pp. 519-23.

${ }^{151}$ Kim Wagner, Thuggee. Banditry and the British in Early Nineteenth-Century India (Basingstoke: Palgrave Macmillan, 2007) pp. 217-26.

152 Hopkins, Afghanistan, pp. 13-18, 41-45.

153 Burnes to Jacob, 25 April 1841, NAI/Foreign/S.C./28 September 1842/Nos.33-42 p. 29.

154 Kaye, History (1874), Vol. II, pp. 164-5, 408-9.

${ }_{155}$ Major General Pollock to T.H. Maddock, 10 July 1842, NAI/Foreign/S.C./28 December 1842/Nos.480-2 Mohun Lall's memorandum on the Disaster at Cabul p. 9750.

${ }^{156}$ Lal to Pollock, 29 June 1842, NAI/Foreign/S.C./28 December 1842/Nos.480-2 p. 9801.
} 
A. Morrison 'Twin Imperial Disasters. The invasions of Khiva and Afghanistan in the Russian and British official mind, 1839 - 1842' Modern Asian Studies Vol.48 No.1 (2014) pp.253 - 300

himself had been sent on an unsuccessful placatory mission), continual disagreements between Macnaghten and Burnes, and finally the indecision and double-dealing in which Macnaghten and Elphinstone had indulged after Burnes's murder. ${ }^{157}$ Yapp has since argued convincingly that, important as all these factors were, the root cause of the rebellion was the prospect many of the Kabul-based Afghan elite faced of seeing their power-base and revenues eroded by the new military structures which the Anglo-Sadozai government was seeking to introduce, but Lal's was surely the earliest complete summary of the failings of British policy and remains one of the most accurate. ${ }^{158} \mathrm{Lal}$ also revealed that he had warned Macnaghten that his life was in danger on the eve of his murder by Dost Muhammad's son, Muhammad Akbar Khan, and begged him not to attend his fatal rendezvous with the Afghan leader, but that he had been ignored. ${ }^{159}$ Lal would later reproduce some of these descriptions and conclusions in his Life of Dost Muhammad Khan, which received a strikingly negative critical reaction. ${ }^{160}$ The reviewer for Blackwood's Edinburgh Magazine described the book as dull, wordy, and stale, adding caustically that in his admiring portrayal of the amir he was 'thus betraying a certain Oriental laxity of principle which European education and Society might be expected to eradicate'. ${ }^{161}$ The Calcutta Review was equally sneering, 'Historical accuracy being thus set aside, as of impossible attainment, Mohan Lal, Esquire, doubtless, determines to compensate for this important deficiency, by extraordinary graces of style- the excellence of the manner atoning for the imperfections of the matter. Not at all.' Instead the reviewer took strong exception to what he saw as the deficiencies of Lal's English, while also accusing him of 'an absence of all capacity to discern the important from the unimportant'. ${ }^{162}$

As Bayly and Hopkins have concluded, the growing British tendency to disregard information from 'native sources' was a crucial factor in the colossal intelligence failures that surrounded the First Afghan War. ${ }^{163}$ In the case of the Khiva expedition, there are clear parallels. The freezing weather may have been beyond Perovsky's control, but he took the decision to continue the advance, even as conditions deteriorated still further—had he turned back earlier many lives would have been saved. Throughout his later memoir of the expedition, Ivanin referred to the Kazakhs on whom the force relied for the management of its camels in the most disparaging terms, as 'asiatics unworthy of entire confidence', and bemoaned the lack of reliable information about routes to Khiva because 'the testimony on these points of the asiatics who have been there, because of their inclination to deceit [obman] and exaggeration, can in no degree be relied upon'. ${ }^{164}$ He often noted the possibility that they might mutiny or go over to the Khivans. Matters came to a head when the columns prepared to move off from the fortification at Aty-Yakshi on the river Emba, which they had only reached with the greatest difficulty, through still deeper snow to the advanced post at Aq Bulaq, when the 300 Kazakh drivers with the leading column refused to

${ }^{157}$ Lal to Pollock, 29 June 1842, NAI/Foreign/S.C./28 December 1842/Nos.480-2 pp. 9769-71, 978283, 9804-09.

158 M.E. Yapp, 'The Revolutions of 1841-2 in Afghanistan', Bulletin of the School of Oriental and African Studies Vol. 27 No. 2 (1964) pp. 333-81.

${ }^{159}$ Lal to Pollock, 29 June 1842, NAI/Foreign/S.C./28 December 1842/Nos.480-2 pp. 9782-83.

160 Mohan Lal, Life of the Amir Dost Mohammed Khan of Kabul (London: Longman, Brown, Green \& Longmans, 1846) Vol. II, pp. 401-29.

161 'Mohan Lal in Afghanistan', Blackwood's Edinburgh Magazine Vol. 60 (November 1846) p. 542.

162 'Life of the Amir, Dost Mahommed Khan of Kabul', The Calcutta Review Vol. VII (January-June 1847) pp. 2-4.

163 Bayly, Empire and Information, pp. 128-40; Hopkins, Afghanistan, pp. 78-81.

164 Ivanin/Golosov, 'Pokhod v Khivu' VS No. 2 (1863) pp. 324-25; Anon, A Narrative, p. 97. 
30 A. Morrison 'Twin Imperial Disasters. The invasions of Khiva and Afghanistan in the Russian and British official mind, 1839 - 1842' Modern Asian Studies Vol.48 No.1 (2014) pp.253 - 300

carry on; when threatened with death, they 'stated that they were all prepared to die, but that to go on was against their faith, and that caravans never travelled when there was such a frost'. ${ }^{165}$ Two of the ringleaders were then seized and shot, and the crowd eventually dispersed. Revealingly, when Perovsky reminisced about this incident during a recuperative sojourn in Rome, he transformed it into a grotesque anecdote about a 'mullah' accompanying the expedition, who refused to obey orders and only yielded once Perovsky had shot two of his sons and was about to send the third to the firing-squad. ${ }^{166} \mathrm{He}$ had chosen to remember it as an instance of Islamic 'fanaticism', an interpretation echoed in several other Russian accounts of the 'mutiny' and subsequent executions: all refer to this as a moment of crisis, where Perovsky's decisive action saved the column from being stranded in the steppe by their unreliable Kazakh allies. Ivanin also attributed the rebellion to Kazakh 'fanaticism' stimulated by Khivan propaganda, placing great emphasis on the 'wild shouts' of the Kazakhs and saying nothing about the more practical objections of the drivers to proceeding any further. ${ }^{167}$ Peslyak, however, wrote that it was the freezing conditions that caused the Kazakh drovers to try to halt the expedition, ${ }^{168}$ and Dal' wrote that the Kazakhs claimed the camels were simply not up to the journey. ${ }^{169}$ There is also a striking contrast between what Perovsky reported the Kazakhs as saying in his original missive and the reasons he then adduces for their discontent. It seems clear that it was the sheer insanity of trying to travel in the steppe under such conditions that had aroused the drivers' anger, not fears of a possible Khivan attack. In effect they were telling Perovsky what he would belatedly discover for himself a month later at Aq Bulaq, when he announced that the expedition would have to turn back owing to the severity of the weather. ${ }^{170}$ By that time, not only would over half his camels be dead, almost half his men would also be either dead or incapacitated by frostbite and scurvy. In ignoring the views of those who actually lived on the Steppe and failing to turn back earlier, when most of his camels were still alive, Perovsky had been guilty of a folly almost as great as that of Macnaghten and Elphinstone at Kabul.

Whether we view Britain and Russia's aims in the region as being primarily those of annexation or dominance, or take at face value the claims made by their leaders that all they sought were stable frontiers, the protection of trade, and the release of slaves, it is clear that both powers systematically undermined these aims through their failure to regard either Central Asian rulers or Central Asian informants as worthy of serious consideration as equal partners, and instead to assume their 'fanaticism', ignorance, and bad faith from the very outset.

\section{Conclusion}

Khiva would not fall to a Russian army until 1873, and after the punitive expedition they sent to avenge the army of the Indus in the autumn of 1842, it would be almost 40 years before the British were once again drawn into meddling in Afghanistan's internal affairs. Yapp has argued

\footnotetext{
165 Perovsky to Chernyshev, 6 January 1840, Serebrennikov Sbornik Vol. II Doc. 4 p. 3.

166 'Pis'ma grafa V. A. Perovskago k A. Ya. Bulgakovu', RA, No. 7 (1878) p. 314.

${ }_{167}$ Ivanin/Golosov, 'Pokhod v Khivu', VS No. 3 (1863) p. 32-3; Anon, Narrative, p. 149; Ivanin, Opisanie, pp. 125-26.

168 Peslyak, 'Zapiski', p. 586.

${ }_{169}$ Dal', 'Pis'ma k druzyam', 27 December 1839, RA, Vyp.3 (1867) pp. 430-31.

170 'Prikaz po otryadu voisk Khivinskoi ekspeditsii', 1 February 1840, Serebrennikov Sbornik Vol. II Doc 22 p. 42; an English translation of this document can be found in Anon, Narrative, pp. 165-66.
} 
A. Morrison 'Twin Imperial Disasters. The invasions of Khiva and Afghanistan in the Russian and British official mind, 1839 - 1842' Modern Asian Studies Vol.48 No.1 (2014) pp.253 - 300

that both the British and the Russians suffered severe rebuffs and realized that the costs of a 'forward strategy' in Central Asia outweighed the likely benefits. ${ }^{171}$

Although the First Afghan War almost bankrupted the East India Company, ${ }^{172}$ and the British certainly drew in their horns after 1842, the pace of expansion hardly slackened, as first Sind and then Punjab were annexed between 1843 and 1849, though this was in many ways a consequence of the failure of the Afghan strategy of frontier defence. The fear that rumours of a Russian advance might provoke rebellion in India remained persistent, even after the Anglo-Russian agreement of 1907, but with these caveats Yapp's conclusion seems fair. ${ }^{173}$

The lessons Russia learned from the Khivan disaster (which was less financially damaging) were more complicated. First, it was not until 1842 that it became clear that the British adventure in Afghanistan had been a catastrophe. Before then, the Russians felt that they had been comprehensively outmanoeuvred (or at any rate out-spent) by the British in Central Asia. In January 1840 Major-General Verigin urged that the occupation of Khiva be made permanent once the expedition reached its destination, claiming that otherwise — instigated by the English and with the aid of their skilled officers' - the khanate would improve its defences and prove resistant to future attacks. ${ }^{174}$ The expedition's failure rendered such a scheme impossible and deepened Russian worries still further. Perovsky wrote vehemently to Nesselrode that once Afghanistan had fallen, Bukhara could be next. ${ }^{175}$ Duhamel also wrote from Tehran that British influence would soon spread from Afghanistan to the Caspian littoral, snuffing out Russian trade and other interests and compromising its security. ${ }^{176}$ In the same despatch Duhamel also complained about Richmond Shakespear's activities in Khiva. Russian paranoia was reinforced by the presence of British agents beyond the Oxus. However inept James Abbott's mission to Khiva appears with hindsight, he certainly succeeded in annoying Perovsky, who fulminated over his presumption and the flimsiness of his credentials. ${ }^{177}$ Perovsky and Nesselrode agreed that as Abbott's reception in Khiva did not appear to have been particularly friendly or to have achieved a great deal, it would be unwise to worsen relations with Britain by punishing him for what they regarded as an illegitimate intrusion into Russia's foreign affairs. ${ }^{178}$ In September, however, came the unwelcome news that Richmond Shakespeare had turned up at the Novo-Alexandrovsk

171 Yapp, Strategies, pp. 413-18, 460.

172 Indeed, the Company's credit with Indian bankers, which had been crucial to funding the occupation, was well-nigh exhausted by 1842, when many refused to accept bundis (or notes of hand) signed by its officers. Shah Mahmoud Hanifi, 'Impoverishing a Colonial Frontier: Cash, Credit, and Debt in NineteenthCentury Afghanistan', Iranian Studies Vol. 37 No. 2 (June 2004) pp. 199-218.

${ }^{173}$ Jennifer Siegel, Endgame. Britain, Russia, and the final Struggle for Central Asia (London: I. B. Tauris, 2002) pp. 48-50, 145, 197-201.

174 'Dopolnenie k zapiske Gen-m Verigina, predstavlennoi im v 1826 godu’, 13 January 1840, Serebrennikov Sbornik Vol. II Doc. 5 p. 15.

175 Perovsky to Nesselrode, 6 May 1841, AVPRI F.161 I-9 D.5 1l.483-487 in Kazakbsko-russkie otnosheniyav XVIII-XIX vekakh (1771-1867 gody) (Alma-ata, 1964) pp. 293-94.

176 Duhamel to Nesselrode, 05 February 1841, AVPRI, F.133 Op.469 1841g. D.213 'Téhéran (Affaires de l'Asie)' $11.54 o b-56$

177 Perovsky to Nesselrode, 28 May 1840, Serebrennikov Sbornik Vol. II Doc. 92 pp. 146-47

178 Nesselrode to Perovsky, 5 April 1840; Perovsky to Nesselrode, 8 July 1840 Serebrennikov Sbornik Vol. II Docs.106 and 108 pp. 180-85. 
32 A. Morrison 'Twin Imperial Disasters. The invasions of Khiva and Afghanistan in the Russian and British official mind, 1839 - 1842' Modern Asian Studies Vol.48 No.1 (2014) pp.253 - 300

fortress with 416 liberated Russian slaves: this was a more substantial blow, as he appeared to have achieved single-handedly what the winter expedition of $1839-40$ had failed to. ${ }^{179}$

Even before the remains of the Khivan expedition had returned to Orenburg, officials were raising the question of how to maintain Russia's prestige in Central Asia and counter perceptions of weakness. Prince Menshikov proposed a fort on the Syr-Darya as a means of responding to the debacle: 'The taking of Kabul by the English and the approach of their forces to Bukhara must now, without doubt, be considered the main factor opposed to our influence', and that the best means of combating it was to project Russian influence deep into the Steppe through fortifications. ${ }^{180}$ This would become the cornerstone of future Russian policy in Central Asia. Although the British were so scarred by their experience in Afghanistan that they left it alone for 40 years, the Russians drew practical lessons from the failure of the Khivan expedition and did not abandon their determination to subdue both the nomadic peoples who populated the empire's southern frontier and the sedentary states beyond them, which they assumed were responsible for most of the military problems they encountered in the Steppe. As Ivanin put it in a dyspeptic response to the unauthorized publication of his reminiscences, the expedition had taught some tactical lessons about steppe warfare. ${ }^{181}$ Perovsky's failure had shown that the difficulties of movement and maintaining supply lines needed for steppe campaigning meant that long-distance expeditions were not feasible. Instead the Russians would push their frontier south by building a new line of fortresses, beginning in 1845 with the construction of small forts on the rivers Irgiz and Turgai by the new governor of Orenburg, General Obruchev.

Neither power learned the most important lessons of all from these debacles. The first was that their fear of each other's intentions in the region had been exaggerated by ambitious 'men on the spot' until they became mutually reinforcing — a 'contest to get there first', which led them into serious errors. ${ }^{182}$ The second was that, even following their own imperialist logic, they should have listened to the advice, opinions, and intelligence provided by Central Asians themselves. A comparison of the origins of these twin imperial disasters thus reveals that the Russian 'official mind' - the assumptions, prejudices, and mental universe of its ruling military elite-was remarkably similar to that of its British counterpart in India. Like the British, the Russians did not see Central Asia's states as rational, sovereign polities open to the usual niceties of diplomacy and negotiation, but as savage, backward, unreliable, and amenable only to force. The only difference was that, while British fears of the extension of Russian influence into Afghanistan were largely illusory, Russian attempts to counter their exclusion from Afghanistan by the British succeeded in triggering a very real invasion and occupation that, for a while, seemed to have dealt a heavy blow to Russian prestige and trade in the region. The subsequent catastrophic collapse of the AngloSadozai regime came about because of local factors of which the Russians had been entirely ignorant.

Forty years before the 'Scramble for Africa', during a period of what is often seen as largely unchallenged British global hegemony, where 'informal' influence sufficed to defend British

\footnotetext{
179 Perovsky to Chernyshev, 26 November 1840 Serebrennikov Sbornik Vol. II Doc. 133 p. 217.

180 'Zapiska knyazya Menshikova o predpolozhenii osnovat' na r. Syr-Dar'e sil'noe ukreplenie s poseleniem', 4 March 1840 Serebrennikov Sbornik Vol. II Doc. 43 pp. 72-73.

${ }^{181}$ Ivanin, 'Zametki', p. 484.

182 Frankel, 'Towards a Decision-making Model', p. 5.
} 
A. Morrison 'Twin Imperial Disasters. The invasions of Khiva and Afghanistan in the Russian and British official mind, 1839 - 1842' Modern Asian Studies Vol.48 No.1 (2014) pp.253 - 300

interests, competition with another European power was already a key determinant of imperial expansion in Asia. ${ }^{183}$

Russian insecurities and their wariness of British dominance are less surprising, but it is striking how often their language of fear and vulnerability was echoed on the British side. As with Egypt, Sudan, and East Africa in the 1880s and 1890s, the invasions of Afghanistan and Khiva were preemptive and intended to thwart the imagined designs and intrigues of another European power on a piece of territory. ${ }^{184}$ Robinson and Gallagher also note that a key factor in British expansion in Africa was the profound distrust and ignorance of the 'official mind' when confronted with 'native' leaders such as 'Urabi Pasha, whom it considered to be 'fanatical' and impossible to negotiate with. ${ }^{185}$ Once again, there was nothing new in this attitude: it was another facet of the growing racial arrogance and intolerance which, as Bayly has shown, gradually crippled British intelligence networks within India, culminating in the domestic disasters of 1857. ${ }^{186}$ Twenty years before this, mutually reinforcing fears of British and Russian intrigue, combined with a refusal to take 'native' sources or 'native' rulers seriously, had produced twin foreign policy disasters on a similar scale.

\footnotetext{
183 Robinson and Gallagher, Africa and the Victorians, pp. 464-65; Darwin, 'Imperialism and the Victorians', pp. 625-31.

${ }_{184}$ Robinson and Gallagher, Africa and the Victorians, pp. 304-06, 339-78.

${ }^{185}$ Robinson and Gallagher, Africa and the Victorians, pp. 466-67.

186 Bayly, Empire and Information, pp. 165-77, 315-18.
} 